OPEN ACCESS

Edited by:

Ayşen Tezcaner, Middle East Technical

University, Turkey

Reviewed by: Vesna Miskovic-Stankovic, University of Belgrade, Serbia

Giovanni Vozzi.

University of Pisa, Italy

*Correspondence: Bowei Wang wangbw@jlu.edu.cn

Specialty section This article was submitted to Biomaterials,

a section of the journal

Frontiers in Materials

Received: 03 January 2021 Accepted: 23 February 2021 Published: 18 March 2021

Citation:

Liu D, Liu Z, Zou J, Li L, Sui X, Wang B, Yang $N$ and Wang $B$ (2021) Synthesis and Characterization of a Hydroxyapatite-Sodium Alginate-Chitosan Scaffold for Bone Regeneration. Front. Mater. 8:648980.

doi: 10.3389/fmats.2021.648980

\section{Synthesis and Characterization of a Hydroxyapatite-Sodium Alginate-Chitosan Scaffold for Bone Regeneration}

\author{
Dingkun Liu 1,2, Zhihui Liu ${ }^{3}$, Jundong Zou ${ }^{2}$, Lingfeng $\mathrm{Li}^{2}$, Xin Sui ${ }^{2}$, Bizhou Wang ${ }^{2}$, \\ Nan Yang ${ }^{2}$ and Bowei Wang ${ }^{1 *}$ \\ ${ }^{1}$ The Second Hospital, Jilin University, Changchun, China, ${ }^{2}$ Jilin Provincial Key Laboratory of Tooth Development and Bone \\ Remodeling, Hospital of Stomatology, Jilin University, Changchun, China, ${ }^{3}$ Hospital of Stomatology, Jilin University, \\ Changchun, China
}

Bone scaffolds play an important role in promoting the healing of large bone defects. However, the type of scaffold material, type of drug loaded into the scaffold, and method of preparation have a significant impact on the scaffold's properties. In this study, we developed a composite scaffold comprising sodium alginate (SA), chitosan (CS), and hydroxyapatite (HA). The composite stent carries vascular endothelial growth factor (VEGF), wrapped in internal microspheres, and vancomycin (VAN). The microspheres are wrapped in an outer matrix formed by SA, CS, and HA, whereas the outer matrix carries VAN. Using Fourier-transform infrared spectroscopy (FTIR), X-ray diffraction, and scanning electron microscopy analyses, we studied the contraction rate, swelling, porosity, mechanical properties, degradation, and drug release ability of all the composite scaffolds. The best scaffold, as demonstrated by the results of these studies, was the $\mathrm{HA}_{6}(\mathrm{SA} / \mathrm{CS})_{4} @$ VAN/NEGF scaffold. The antibacterial ability of the $\mathrm{HA}_{6}(\mathrm{SA} / \mathrm{CS})_{4} @$ VAN/VEGF scaffold was determined using Staphylococcus aureus (S. aureus). Cytotoxicity, cell adhesion, and osteogenic properties of the $\mathrm{HA}_{6}(\mathrm{SA} / \mathrm{CS})_{4} @$ VAN/NEGF scaffold were studied using bone marrow mesenchymal stem cells. The results indicate that the $\mathrm{HA}_{6}(\mathrm{SA} / \mathrm{CS})_{4} @$ VAN/VEGF scaffold exhibits good physical, chemical, antibacterial, and osteogenic properties, and is, thus, a new type of bone scaffold composite material with good osteogenic potential.

Keywords: bone regeneration, composite scaffold, drug release, osteogenesis, bone defects, hydroxyapatite, chitosan, sodium alginate

\section{INTRODUCTION}

Bone defects are usually caused by trauma, infection, surgery, and diseases, such as osteoporosis and arthritis, and bone tissue replacement is required to rebuild function (Wei et al., 2020). As the body itself cannot repair large bone defects, tissue healing must be promoted through surgical intervention. At present, autologous and allogeneic bone transplantations are the main clinical treatment modalities. However, the risks of secondary infection, immune rejection, donor disease, and limited blood supply need to be circumvented through artificial replacement using bone tissue engineering (Smith et al., 2015; Windhager et al., 2017). Therefore, the development of appropriate 
tissue engineering techniques may help circumvent the above shortcomings and accelerate tissue regeneration (Montalbano et al., 2020).

Bone repair is a long-term process, and tissue engineering can be used to promote bone repair. An ideal bone scaffold should have components, structure, and biomechanical properties similar to those of natural bone, serve as a base for bone deposition and provide mechanical support, regulate cell adhesion, proliferation, and differentiation, and provide cells with a microenvironment for osteogenic differentiation (Hao et al., 2017; Kim et al., 2020; Shen et al., 2021). Using bone tissue engineering technology a bone scaffold material carrier can be constructed carrying seed cells and biological factors, and then implanted in the bone defect, to promote bone formation. The development of this new technology eliminates the disadvantages of autogenous and allogeneic bone transplantations. In addition, by adding different biological factors, the process of bone repair can be accelerated and the treatment time can be shortened.

There are two main ways of bone regeneration: intraosseous and cartilage osteogenesis. Among them, osseous osteogenesis is manifested by the direct differentiation of mesenchymal stem cells (MSCs) into osteoblasts. After extracellular matrix secretion, the mineralization is further deposited and the bone defect is finally restored (Loi et al., 2016; Lin et al., 2018). Bone marrow stem cells (BMSCs), which have a great potential to be used as seed cells, play an important role in promoting the regeneration of tissues including bone tissue, skin and blood vessel, nerve tissue, and myocardial tissue (Raynald et al., 2019; Ribeiro et al., 2019; Zhang et al., 2019; Arthur and Gronthos, 2020). BMSCs have become the preferred cell type for bone tissue engineering, and their use has been gradually transferred from the experimental to the clinical stage contributing to obtaining better bone tissue healing outcomes (Hashimoto et al., 2019).

Hydroxyapatite (HA) is the main inorganic component of human bone tissue, showing high biocompatibility, biological activity, and bone formation ability (Koc et al., 2016; Nie et al., 2017; Melo et al., 2020). Furthermore, HA is considered as one of the most promising bone implant materials. However, its high brittleness and low mechanical strength restrict its clinical application. Therefore, HA is often used to form composites with other macromolecules and high-molecular polymers, which can show better bone-forming ability to meet the requirements for ideal bone scaffold materials (Saleem et al., 2020).

Sodium alginate and chitosan are common biological macromolecules (Luo et al., 2018; Arafa et al., 2020). When used with hydroxyapatite, they can promote tissue regeneration and play an important role in bone tissue engineering. However, in current research, these three mixtures are mostly made into hydrogels, bone cements, etc., which are used to promote tissue regeneration and drug delivery (Lima et al., 2020; Zima et al., 2020). The material synthesized by the above preparation method has the disadvantages of low strength, fast degradation rate, single drug-loaded, and so on (Zou et al., 2021). In addition, there are simple microspheres prepared from these three materials for sustained drug release (Bi et al., 2019), but when such microspheres are placed in the body, their position cannot be well-restricted, and they tend to leave the placement area with body fluid circulation and body position changes. Therefore, stent materials with high strength and multiple drug loading can better solve the above-mentioned shortcomings.

Vascular endothelial growth factor (VEGF) is a key physiological angiogenesis regulator in embryonic development and after birth, which can promote the proliferation and migration of endothelial cells and increase the permeability of blood vessels (Uccelli et al., 2019). Current research show that VEGF, in addition to playing an important role in vascular regeneration, also plays an active role in bone regeneration. VEGF plays an important role in different stages of bone tissue repair, including inflammation, endochondral ossification, intramembranous ossification, and bone remodeling in the process of callus formation, and affects the proliferation and differentiation of osteoblasts ( $\mathrm{Hu}$ and Olsen, 2016). The vascular endothelial growth factor is contained in the scaffold material to promote bone tissue regeneration (Garcia et al., 2016; Chen et al., 2020). At the same time, studies have shown that when sodium alginate is loaded with VEGF, the two are electrostatically combined and will not affect VEGF (Gu et al., 2004). Therefore, VEGF is of great significance for the treatment of bone non-union that is prone to occur in large bone defects.

Bone tissue infection, especially osteomyelitis, is a tricky situation. Therefore, it is necessary to use antibiotics while promoting bone tissue regeneration in order to achieve a good osteogenic effect. Vancomycin (VAN) is widely used clinically as a high-level antibiotic, especially as the antibiotic of choice for methicillin-resistant $S$. aureus (De Vriese and Vandecasteele, 2014). The antibacterial mechanism of vancomycin is to inhibit the peptidoglycan synthesis pathway of the bacterial cell wall (Garcia-Gonzalez et al., 2018). It can be carried in the scaffold and released for a long time to promote bone tissue regeneration without affecting the activity of bone marrow mesenchymal stem cells (Cheng et al., 2018; Yu et al., 2020; He et al., 2021).

Therefore, VAN can be loaded in the scaffold material to achieve a local slow-release of the antibiotic, which is beneficial to the entire osteogenic microenvironment and ultimately promotes bone tissue regeneration. Furthermore, studies have shown that the VAN-loaded scaffold ultimately leads to the formation of a better bone tissue structure (Zhou et al., 2018; Avani et al., 2019).

The aim of this study is to prepare a composite scaffold that possesses an antibacterial action and promotes bone tissue regeneration. We have prepared a stent that can carry two drugs simultaneously, so that the release of the two drugs has a chronological sequence to meet the needs of different stages of bone regeneration. The physical and chemical properties such as swelling, degradation, porosity, and the mechanical properties of the scaffold were evaluated; co-cultivation with BMSCs was also conducted using in vitro experiments to evaluate their ability to promote bone tissue regeneration.

\section{EXPERIMENTAL SECTION}

\section{Materials and Instruments}

The following materials were used in this study: SA, with viscosities of 4-12 and $20 \mathrm{mPa}$ - s (Aldrich Sigma, MO, USA), CS, with a deacetylation degree of $80.00-95.0 \%$, viscosity 
of $50-800 \mathrm{mPa}$ - s (Sinopharm Group Chemical Reagent Co., Ltd.), HA (Aldrich Sigma, MO, USA), VAN, with a potency of 906.3 IU (Biosharp, USA), VEGF and its ELISA kit (PeproTech, USA), anhydrous calcium chloride $\left(\mathrm{CaCl}_{2}\right)$, glacial acetic acid, sodium citrate, no water ethanol, analytically pure (Beijing Chemical Plant), $0.1 \mathrm{~mol} / \mathrm{L}(\mathrm{pH}$ $=7.4$ ) phosphate buffer solution (PBS) (prepared in the laboratory). Healthy specific pathogen free (SPF) grade rats weighing 70-100 g (Liaoning Changsheng Biotechnology Co., Ltd., China), low glucose Dulbecco's Modified Eagle's Medium (L-DMEM), $100 \mathrm{U} / \mathrm{mL}$ penicillin, $100 \mathrm{lg} / \mathrm{mL}$ streptomycin and $0.25 \%$ trypsin (Hyclone, USA), rat bone marrow mesenchymal stem cell medium and mesenchymal stem cells-adipocyte differentiation medium (Sciencell, USA), fetal bovine serum (FBS, BI, Israel), methyl thiazolyl tetrazolium (MTT), $\beta$ glycerol phosphate, ascorbic acid and dexamethasone (Sigma, USA), $1 \%$ alizarin red $\mathrm{S}$ staining solution, oil red $\mathrm{O}$ staining solution, BCIP/NBT alkaline phosphatase color development kit, RIPA lysis buffer, phenylmethanesulfonyl fluoride (PMSF), BCA protein assay kit and DAPI staining solution (Beyotime, China), body fluid calcium concentration colorimetric quantitative detection kit (Shanghai Haling Biological Technology Co., Ltd., China), cell total RNA isolation kit (Foregene, China), PrimeScript $^{\mathrm{TM}}$ RT reagent Kit with gDNA Erase, primers including alkaline phosphatase (ALP), runx-related transcription factor 2 (RUNX2), bone morphogenetic protein 2 (BMP2) and osteopontin (OCN) and TB Green ${ }^{\circledR}$ Premix Ex Taq ${ }^{\text {TM }}$ II RT-PCR (Takara, Japan).

The following instruments were used in this study: ALPHA 12LD freeze dryer (Marin Christ, Germany), constant temperature $\mathrm{CO}_{2}$ incubator (Thermo, USA), automatic microplate reader (Bio-TEX, USA), inverted fluorescence microscope and FV3000 laser confocal microscope (Olympus, Japan), Mx3005P fluorescence quantitative PCR instrument (Stratagene, Japan).

\section{Preparation of Multi-Layer Sustained-Release Microspheres Preparation of Core Spheres}

Core spheres were prepared according to a previously published method (Yang et al., 2015). Briefly, $25 \mu \mathrm{g}$ of VEGF was dissolved in $20 \mathrm{ml} 4 \%$ (w/v) SA solution (20 cpSA dissolved in high pressure steam-sterilized deionized water), and stirred evenly to obtain a VEGF-SA solution. Thirty milliliter $15 \%(\mathrm{w} / \mathrm{v}) \mathrm{CaCl}_{2}$ solution (autoclaved) was extracted and put into the beaker. A syringe with a 5 gauge syringe needle was used to suck the VEGF-SA solution, subsequently the solution was dripped into the $\mathrm{CaCl}_{2}$ solution at a uniform speed, and stirred at $300 \mathrm{r} / \mathrm{min}$ for $30 \mathrm{~min}$ to ensure the SA and $\mathrm{Ca}^{2+}$ were fully cross-linked. After the reaction was completed, the residual liquid was suction-filtered, sterilized, and deionized. After washing with water, another suction filtration was performed to obtain the calcium alginate core ball.

\section{Preparation of the Multi-Layer Ball}

A total of $30 \mathrm{ml}$ of $1 \%(\mathrm{w} / \mathrm{v}) \mathrm{CS}$ acetic acid solution was added in a beaker and stirred at a low speed. The CA core ball prepared in the previous step was added to the CS solution and stirred at
TABLE 1 | The formulations of the scaffolds.

\begin{tabular}{|c|c|c|c|c|c|}
\hline Sample & HA (\%) & SA (\%) & CS (\%) & VEGF & VAN \\
\hline $\mathrm{HA}_{0}(\mathrm{SA} / \mathrm{CS})_{10}$ & - & 80 & 20 & - & - \\
\hline $\mathrm{HA}_{4}(\mathrm{SA} / \mathrm{CS})_{6}$ & 40 & 48 & 12 & - & - \\
\hline $\mathrm{HA}_{5}(\mathrm{SA} / \mathrm{CS})_{5}$ & 50 & 40 & 10 & - & - \\
\hline $\mathrm{HA}_{6}(\mathrm{SA} / \mathrm{CS})_{4}$ & 60 & 32 & 8 & - & - \\
\hline $\mathrm{HA}_{7}(\mathrm{SA} / \mathrm{CS})_{3}$ & 70 & 24 & 6 & - & - \\
\hline $\mathrm{HA}_{0}(\mathrm{SA} / \mathrm{CS})_{10} @ \mathrm{VEGF} / \mathrm{NAN}$ & - & 80 & 20 & + & + \\
\hline $\mathrm{HA}_{6}(\mathrm{SA} / \mathrm{CS})_{4} @ \mathrm{VEGF} / \mathrm{NAN}$ & 60 & 32 & 8 & + & + \\
\hline
\end{tabular}

$500 \mathrm{r} / \mathrm{min}$ for $10 \mathrm{~min}$. The residual liquid was filtered, rinsed with sterile deionized water, and then suction-filtered again to obtain a CA-CS double-layer ball. Thirty milliliters of $0.5 \%$ (w/v) sodium alginate solution (4-12 cpSA dissolved in deionized water and sterilized by high pressure steam) was added in a beaker, and stirred at a low speed. The CA-CS double-layer ball prepared in the previous step was added to the above solution, and stirred at $800 \mathrm{r} / \mathrm{min}$ for $2 \mathrm{~min}$. The residual liquid was filtered, rinsed with sterile deionized water, and then filtered again to obtain the CA-CS-SA three-layer ball. Next, $30 \mathrm{ml}$ of $1 \%(w / v)$ CS acetic acid solution was added in a beaker and stirred at a low speed. The CA-CS-SA three-layer ball prepared in the previous step was added to the CS solution, and stirred at $500 \mathrm{r} / \mathrm{min}$ for $10 \mathrm{~min}$. The residual liquid was suction-filtered, rinsed with sterile deionized water and then suction filtered again to obtain the CA-CS-SA-CS four-layer ball. After freeze-drying, the ball was stored at $-80^{\circ} \mathrm{C}$.

\section{Preparation of the HA-Reinforced Ball-Bearing Stent}

An HA-enhanced ball carrier was prepared with a component ratio of $10 \%$ (microsphere volume to total stent volume). According to $6 \%(\mathrm{w} / \mathrm{v})$ CS acetic acid solution to $2 \%(\mathrm{w} / \mathrm{v})$ alginic acid, the sodium solution was prepared in a ratio of $1: 4$, and the SA-CS mixture was prepared by adding $1 \mathrm{~mol} / \mathrm{L} \mathrm{NaOH}$ solution dropwise to adjust the $\mathrm{pH}$ to 7.0-7.4. HA was weighed according to the ratio of SA/CS: HA to 6:4, 5:5, 4:6, and 3:7, respectively. The SA/CS/HA mixed solution was prepared by first adding HA weighed in proportion to $1 \%$ VAN aqueous solution. The SA/CS solution was added after ultrasonic dispersion for $10 \mathrm{~min}$, and the mixture was stirred at $800 \mathrm{r} / \mathrm{min}$ for $30 \mathrm{~min}$. The previously prepared microspheres were added to the mixed solution at a volume ratio of $10 \%$, and stirred at $300 \mathrm{r} / \mathrm{min}$ for $10 \mathrm{~min}$. After the microspheres were evenly distributed, the total solution was placed in the mold, kept overnight at $-20^{\circ} \mathrm{C}$, and then stored at $-80^{\circ} \mathrm{C}$ for $24 \mathrm{~h}$. After freeze-drying, it was soaked in $3 \%(\mathrm{w} / \mathrm{v})$ $\mathrm{CaCl}_{2}$ for $1 \mathrm{~h}$, rinsed gently with sterile deionized water 3 times, placed again overnight at $-20^{\circ} \mathrm{C}$, then stored at $-80^{\circ} \mathrm{C}$ for $24 \mathrm{~h}$, and freeze-dried for use. Table 1 summarizes the formulations of scaffolds.

\section{Characterization}

\section{Composition and Internal Structure Analyses}

To ensure HA successfully modified SA/CS, we used FTIR spectroscopy to show that HA is present in the composite 
scaffold. Four sets of composite scaffolds and raw materials were dried and crushed into powder, and analyzed using FTIR spectroscopy. To further determine the crystal phase of HA in the composite scaffold, we recorded it on a Rigaku D/Max 2550 Xray diffractometer using X-ray diffraction (XRD), with a scanning speed of $8^{\circ} \mathrm{min}^{-1}$ and a diffraction angle range of $20^{\circ}-70^{\circ}$. Transmission electron microscopy (TEM) images were obtained using a Philips Feitner G2STwin microscope, equipped with a field emission gun operating at $200 \mathrm{kV}$.

\section{Contraction Percentage Measurement}

The HA-reinforced ball-bearing stent was fabricated using a 24hole plate as a mold, and a cylindrical stent. The diameter $\left(\mathrm{d}_{1}\right)$ and the height of $1 / 2$ of the diameter of the stent were measured $\left(h_{1}\right)$. The volume of the stent $\left(V_{1}\right)$, and the volume of the stent fluid injected into each hole $\left(\mathrm{V}_{0}\right)$ were calculated. Three parallel groups were prepared for each group of samples, and the average value was calculated. The contraction percentage $(C)$ was measured using the following formula: $\mathrm{C}=\left(\mathrm{V}_{0}-\mathrm{V}_{1}\right) / \mathrm{V}_{0} \times 100 \%$.

\section{Swelling Behavior}

The water absorption and swelling rate of the stent were calculated based on a previous report (Sharmila et al., 2020) and the dry weight $\left(\mathrm{m}_{0}\right)$ of the stent was determined. The stent was submerged in PBS in a centrifuge tube. The centrifuge tube of the submerged support was placed in a shaker, and oscillated for $24 \mathrm{~h}$ at $37^{\circ} \mathrm{C}$, at $60 \mathrm{r} / \mathrm{min}$. Then, it was weighed and three parallel groups were set for each group. The average value was calculated. The swelling rate $(\mathrm{S})$ was determined using the following formula: $\mathrm{S}=\left(\mathrm{m}-\mathrm{m}_{0}\right) / \mathrm{m}_{0} \times 100 \%$.

\section{Mechanical Properties}

An electronic universal testing machine was used to measure the compressive elastic modulus of the dry cylindrical support. The temperature was set at $23^{\circ} \mathrm{C}$, the constant strain rate was 1 $\mathrm{mm} / \mathrm{min}$, and 3 parallel groups were set for each group.

\section{Degradation Studies}

The freeze-dried scaffold was weighed $\left(\mathrm{m}_{0}\right)$, immersed in a centrifuge tube containing sterile $\mathrm{PBS}$, and placed in a $37^{\circ} \mathrm{C}$ cell incubator. Every 3 days, it was carefully rinsed three times with sterile deionized water, and weighed $\mathrm{m}_{\mathrm{x}}$ after freeze-drying. Three parallel groups were set for each group, and the average value was calculated. Then, the scaffold was submerged again in a centrifuge tube containing sterile PBS. The above steps were repeated for 21 days. The remaining bracket mass fraction (D, \%) was calculated using the following formula: $\mathrm{D}=\mathrm{m}_{\mathrm{x}} / \mathrm{m}_{0} \times 100 \%$.

\section{Porosity Measurement}

The absolute porosity of the scaffold material was determined using the liquid ethanol replacement method. $V_{1}$ is the initial volume of absolute ethanol in the container. The stent was placed in absolute ethanol for $5 \mathrm{~min}$ to ensure that the liquid completely filled the pores. The liquid volume at this stage is called $\mathrm{V}_{2}$. Then, the stent was removed from the liquid and the volume of the remaining liquid $\mathrm{V}_{3}$ was determined (Tohamy et al., 2018). The porosity (P) was calculated using the formula: $\mathrm{P}=$ $\left(\mathrm{V}_{1}-\mathrm{V}_{3}\right) /\left(\mathrm{V}_{2}-\mathrm{V}_{3}\right) \times 100 \%$.

\section{Drug Release Evaluation}

The freeze-dried stents were immersed in sterile PBS in centrifuge tubes. VAN was detected on days 1, 2, 3, 4, and 5, and all the sustained-release was removed. The solution was placed at $-80^{\circ} \mathrm{C}$. VEGF was detected on days $1,3,6,9,12$, and 16 . The slow-release solutions were placed at $-80^{\circ} \mathrm{C}$, and the same amount of sterile PBS was then added to the centrifuge tube. The solution was added to a test tube, three parallel groups were set for each group and the average was calculated. VEGF was detected using an ELISA kit, while VAN was detected using a microplate reader.

\section{Antibacterial Assay}

In this study, the gram-positive bacterium $S$. aureus was used to evaluate the antibacterial activity of the scaffold materials. An antibacterial activity test was conducted using a combination of qualitative and quantitative methods. For quantitative analysis, frozen tryptic soy broth (TSB) liquid medium was used to activate frozen $S$. aureus in a $120 \mathrm{r} / \mathrm{m}$ shaking incubator. Subsequently, $5 \mathrm{ml}$ of TSB liquid medium was used to transfer the activated $S$. aureus into each centrifuge tube, which was fixed at an OD value of $0.1-0.2$ at $625 \mathrm{~nm}$. Then, the TSB medium containing $S$. aureus in each test tube was cocultured with the $\mathrm{HA}_{6}$ (SA/CS $)_{4} @ V A N / V E G F, \mathrm{HA}_{6}(\mathrm{SA} / \mathrm{CS})_{4}$, $\mathrm{HA}_{0}(\mathrm{SA} / \mathrm{CS})_{10} @ \mathrm{VAN} / \mathrm{VEGF}$, and $\mathrm{HA}_{0}(\mathrm{SA} / \mathrm{CS})_{10}$ scaffolds, with 4 parallel samples in each group. Subsequently, the mixture was incubated at $37^{\circ} \mathrm{C}$ for 1,3 , and 5 days, and then the absorbance of each group was monitored using an ultravioletvisible spectrophotometer at $625 \mathrm{~nm}$.

The antibacterial activity of the stent was observed in the bacteriostatic zone of $S$. aureus. The $\mathrm{HA}_{6}(\mathrm{SA} / \mathrm{CS})_{4} @ \mathrm{VAN} / \mathrm{VEGF}$, $\mathrm{HA}_{6}(\mathrm{SA} / \mathrm{CS})_{4}, \mathrm{HA}_{0}(\mathrm{SA} / \mathrm{CS})_{10} @ V A N / V E G F$, and $\mathrm{HA}_{0}(\mathrm{SA} / \mathrm{CS})_{10}$ scaffolds were placed in a $15-\mathrm{mL}$ centrifuge tube; then, $5 \mathrm{ml}$ sterile Ionized water was added, and the scaffolds were incubated at $37^{\circ} \mathrm{C}$ for 1,3 , and 5 days. Next, $S$. aureus suspended in TSB medium $(100 \mu \mathrm{l})$ was inoculated onto the agar plate, which was fixed at an OD value of $0.1-0.2$ at $625 \mathrm{~nm}$, and then sterile filter paper with a diameter of $6 \mathrm{~mm}$ was applied to the plate. A total of $10 \mu \mathrm{l}$ of the release solution from each group of scaffolds on days 1,3 , and 5 was added dropwise onto sterile filter paper. After incubating at $37^{\circ} \mathrm{C}$ for $12 \mathrm{~h}$, the diameter of the bacteriostatic ring was measured, photographed, and the sample was stored.

\section{In vitro Studies \\ Isolation and Culture of BMSCs}

The use of Sprague Dawley rats and all related procedures in the following part were approved by Jilin University Stomatology School Animal Care and Use Committee. They were sacrificed by cervical dislocation and immediately immersed in 75\% ethanol for $10 \mathrm{~min}$. The bilateral femur and tibia were quickly separated under a sterile environment and immersed in LDMEM containing 5\% penicillin-streptomycin. The attached soft tissue was removed and soaked in another clean L-DMEM containing $5 \%$ penicillin-streptomycin. Then, the medullary cavity was exposed by removing the bilateral epiphyseal ends and slowly infused with $5 \mathrm{ml}$ preheated rat bone marrow mesenchymal stem cell medium using a sterile syringe. The 
obtained cells were transferred to a $25 \mathrm{~cm}^{2}$ plastic culture flask for incubation at $37^{\circ} \mathrm{C}$ in a $5 \% \mathrm{CO}_{2}$ supplemented incubator. After $72 \mathrm{~h}$, the fresh medium was changed and then every 3-4 days.

When the cells at $70-80 \%$ confluence, the medium was discarded, rinsed and $0.5 \mathrm{ml} 0.25 \%$ trypsin was added. The digestion was terminated by adding $3 \mathrm{ml}$ complete culture solution when most cells became spherical. The cell suspension was centrifuged at $1,000 \mathrm{rpm}$ for $5 \mathrm{~min}$, the supernatant was discarded, the cells were resuspended in stem cell medium and subcultured at a 1:2 split ratio. Then, the medium was changed every 3 days until the cells reached $70-80 \%$ confluence again. The above passaging process was repeated, and third-generation cells were obtained.

\section{Osteogenic Differentiation of BMSCs}

A total of $500 \mu \mathrm{l}$ of $1 \%$ gelatin was used to coat the bottom surface of a 12-well plate for $30 \mathrm{~min}$. Third-generation BMSCs were used to inoculate the gelatin-coated 12 -well plate at a density of $5 \times 10^{4}$ cells/well. Cells were divided into a blank group and an induction group, each with 3 multi-wells. After adhering, they were induced with osteogenic induction L-DMEM (L-DMEM, 1\% penicillin-streptomycin, 10\% FBS, 0.5\% $1 \mathrm{~mol} / \mathrm{L}$ $\beta$-glycerol phosphate, $1 \% 5 \mathrm{mg} / \mathrm{mL}$ ascorbic acid, $0.5 \% 20 \mathrm{nmol} / \mathrm{L}$ dexamethasone), and the medium was changed every 3 days. After 11 days, the induction and control groups were rinsed twice with $2 \mathrm{ml}$ PBS, fixed for $10 \mathrm{~min}$ with $1 \mathrm{ml} 4 \%$ paraformaldehyde, rinsed three times with $2 \mathrm{ml}$ deionized water, and avoid $1 \mathrm{ml} 1 \%$ alizarin red S staining solution. Next, the cells were incubated for $30 \mathrm{~min}$ away from the light, rinsed five times with $2 \mathrm{ml}$ deionized water. Images were captured using the inverted microscope.

\section{Adipogenic Differentiation of BMSCs}

Third-generation BMSCs were inoculated into a 12 -well plate coated with $1 \%$ gelatin at a density of $5 \times 10^{4}$ cells/well. Cells were divided into blank and induction groups, respectively, with 3 multiple wells. When the cells reached $90-100 \%$ fusion, the cells of induction group were cultured with mesenchymal stem cellsadipocyte differentiation medium and the medium was changed every 4 days. Eleven days later, the medium in the both groups were aspirated and $2 \mathrm{ml}$ PBS was added to rinse twice. Cells were fixed with $1 \mathrm{ml} \mathrm{4 \%}$ paraformaldehyde for $10 \mathrm{~min}$, rinsed twice with $2 \mathrm{ml}$ deionized water, dipped in $60 \%$ isopropyl alcohol for $5 \mathrm{~min}$, incubated with $1 \mathrm{ml}$ of oil red $\mathrm{O}$ stain for $20 \mathrm{~min}$ in the dark, and rinsed five times with $2 \mathrm{ml}$ of deionized water. Images were obtained using the inverted microscope.

\section{Cytotoxicity Evaluation}

Third-generation BMSCs were digested and resuspended separately with complete L-DMEM (L-DMEM containing $10 \%$ FBS and $1 \%$ penicillin-streptomycin), $\mathrm{HA}_{0}(\mathrm{SA} / \mathrm{CS})_{10}$ @VAN/VEGF scaffold extraction and $\mathrm{HA}_{6}(\mathrm{SA} / \mathrm{CS})_{4} @ V A N / V E G F$ scaffold extraction. They were inoculated into a 96-well plate at $5 \times 10^{4}$ cells/well in three wells of each group of four 96-well plate. The plates were taken out on the first day, third day, fifth day, and seventh day, respectively, 20 $\mu \mathrm{l}$ of $5 \mathrm{mg} / \mathrm{mL}$ MTT was added to each well in the dark, and the cells were incubated for $4 \mathrm{~h}$ in the incubator. Then, the medium was removed, $150 \mu \mathrm{l}$ of DMSO solution was added to each well and placed for $10 \mathrm{~min}$ on a shaker until the purple crystals were fully melted. The optical density (OD) values were read using an automatic microplate reader at $490 \mathrm{~nm}$.

\section{Determination of Calcium lon Concentration}

Two $\mathrm{HA}_{0}(\mathrm{SA} / \mathrm{CS})_{10} @ \mathrm{VAN} / \mathrm{VEGF}$ scaffolds and two $\mathrm{HA}_{6}(\mathrm{SA} / \mathrm{CS})_{4} @ V A N / V E G F$ scaffolds were immersed in $20 \mathrm{ml}$ PBS separately, and placed at $4^{\circ} \mathrm{C}$. All the liquid was collected on the first day, the fifth day, the seventh day, and the fourteenth day and fresh $20 \mathrm{ml}$ PBS was added again. After the samples were collected, the concentration calcium ion concentration was determined according to the instruction of the kit for quantitative detection of body fluid calcium ion colorimetry.

\section{Alizarin Red Staining}

A total of $500 \mu \mathrm{l}$ of $1 \%$ gelatin was added to a 12 -well plate, incubated for $30 \mathrm{~min}$ in the ultra-clean bench. Then, the plate was dried for use. Third-generation BMSCs were seeded on a gelatin-coated 12-well plate at a density of $5 \times 10^{4}$ cells/well. Cells were divided into blank, $\mathrm{HA}_{0}(\mathrm{SA} / \mathrm{CS})_{10} @ \mathrm{VAN} / \mathrm{VEGF}$, and $\mathrm{HA}_{6}(\mathrm{SA} / \mathrm{CS})_{4} @ V A N / V E G F$ groups, with three replicate wells per group. When the cells reached $80-90 \%$ of confluence, the medium was replaced with the corresponding osteogenic induction medium, that was, blank groups with osteogenic induction L-DMEM, $\mathrm{HA}_{0}(\mathrm{SA} / \mathrm{CS})_{10} @ \mathrm{VAN} / \mathrm{VEGF}$ groups with $\mathrm{HA}_{0}(\mathrm{SA} / \mathrm{CS})_{10} @ \mathrm{VAN} / \mathrm{VEGF}$ osteogenic induction medium $\left(\mathrm{HA}_{0}(\mathrm{SA} / \mathrm{CS})_{10} @ V A N / V E G F\right.$ scaffold extraction, $1 \%$ penicillin-streptomycin, 10\% FBS, $0.5 \% 1 \mathrm{~mol} / \mathrm{L} \beta$-glycerol phosphate, $1 \% \quad 5 \mathrm{mg} / \mathrm{mL}$ ascorbic acid, $0.5 \% \quad 20 \mathrm{nmol} / \mathrm{L}$ dexamethasone), $\mathrm{HA}_{6}(\mathrm{SA} / \mathrm{CS})_{4} @ \mathrm{VAN} / \mathrm{VEGF}$ groups with $\mathrm{HA}_{6}(\mathrm{SA} / \mathrm{CS})_{4} @ V A N / V E G F$ osteogenic induction medium $\left(\mathrm{HA}_{6}(\mathrm{SA} / \mathrm{CS})_{4} @ \mathrm{VAN} / \mathrm{VEGF}\right.$ scaffold extraction, 1\% penicillinstreptomycin, $10 \% \mathrm{FBS}, 0.5 \% 1 \mathrm{~mol} / \mathrm{L} \beta$-glycerol phosphate, $1 \%$ $5 \mathrm{mg} / \mathrm{mL}$ ascorbic acid, $0.5 \% 20 \mathrm{nmol} / \mathrm{L}$ dexamethasone). After 11 days, all samples were treated with an alizarin red staining solution according to the instruction.

\section{ALP Staining}

On the eleventh day of osteogenic induction, the medium was aspirated. The cells were rinsed twice with $2 \mathrm{ml}$ PBS, fixed with $1 \mathrm{ml} \mathrm{4 \%}$ paraformaldehyde for $15 \mathrm{~min}$, and rinsed three times with $2 \mathrm{ml}$ PBS. Then, these cells were stained, observed, and imaged according to the instructions of BCIP/NBT alkaline phosphatase color development kit.

\section{ALP Viability}

After osteogenic induction for 11 days, the medium was aspirated and the cells were rinsed twice with $2 \mathrm{ml}$ PBS. A total of $300 \mu \mathrm{l}$ of RIPA lysis buffer and PMSF was added to lyse cells on ice for $3 \mathrm{~min}$. The cell lysate was collected by centrifugation at 12,000 $\mathrm{rpm}$, at $5^{\circ} \mathrm{C}$ for $5 \mathrm{~min}$, and then the protein concentration at the supernatant was determined according to the instructions of the BCA protein assay kit. The appropriate ratio was selected to dilute the protein samples, and the ALP kit were followed. The OD values at $405 \mathrm{~nm}$ were read using a microplate reader, and the number of DEA enzyme activity units of ALP was calculated. 
TABLE 2 | Primer sequences for osteogenesis-related genes for real-time PCR.

\begin{tabular}{ll}
\hline Gene & Primer/probe sequence \\
\hline GAPDH & Forward: 5'-GGCACAGTCAAGGCTGAGAATG-3' \\
& Reverse: 5'-ATGGTGGTGAAGACGCCAGTA-3' \\
ALP & Forward: 5'-CAGTGGTATTGTAGGTGCTGTGG-3' \\
& Reverse: 5'-CCTTCTGCTTGAGGTGAGGT-3' \\
BMP2 & Forward: 5'-ACCGTGCTCAGCTCCATCAC-3' \\
& Reverse: 5'-CTATTCCCAAAGCTTCCTGCATTT-3' \\
OPN & Forward: 5'-GCCGAGGTGATAGCTTGGCTTA-3' \\
& Reverse: 5'-TTGATAGCCTCATCGGACTCCTG-3' \\
Runx2 & Forward: 5'-CATGGCCGGGAATGATGAG-3' \\
& Reverse: 5'-TGTGAAGACCGTATGGTCAAAGTG-3'
\end{tabular}

\section{Real-Time PCR Analysis}

After osteogenic induction for 11 days, the medium was aspirated from each group, and the total RNA was extracted using the cell total RNA isolation kit. Total RNA samples with a purity value of 1.8-2.0 were used to perform reverse transcription to synthesize cDNA with the prime Script ${ }^{\mathrm{TM}} \mathrm{RT}$ reagent kit with a gDNA eraser. This process adjusts the RNA concentration of each group so that the total RNA amount in the $20 \mu \mathrm{l}$ reverse transcription system was $1 \mu \mathrm{g}$. The cDNA, osteogenic-related gene primers and TB Green ${ }^{\circledR}$ Premix Ex Taq ${ }^{\text {TM }}$ II kit were used to prepare a $20 \mu \mathrm{l}$ reaction system, which was placed in an eight-connected tube, and the PCR reaction was completed in a qRT-PCR instrument. The osteogenic genes analyzed included ALP, bone BMP2, OPN, and Runx2. The primer sequences of each gene are shown in Table 2.

\section{Cell Adhesion on the Scaffold}

The $\mathrm{HA}_{6}(\mathrm{SA} / \mathrm{CS})_{4} @ V A N / V E G F$ and $\mathrm{HA}_{0}(\mathrm{SA} / \mathrm{CS})_{10} @ \mathrm{VAN} / \mathrm{VEGF}$ scaffolds were, respectively, placed in laser confocal dishes, and were pre-wet for $1 \mathrm{~h}$ with complete L-DMEM. Third-generation BMSCs were digested and inoculated into scaffolds at $1.0 \times 10^{6}$ cells/scaffold by repeated dropwise addition. After $1 \mathrm{~h}$, the medium was added until the scaffolds were immersed and placed in a $\mathrm{CO}_{2}$ constant temperature cell incubator. Twenty-four hours later, the medium was discarded, the scaffolds were rinsed twice with pre-warmed PBS, fixed for $10 \mathrm{~min}$ with $4 \%$ paraformaldehyde, and rinsed twice with PBS again. Then, $0.1 \%$ triton $\mathrm{X}-100$ was added to pass through the cell membranes for $5 \mathrm{~min}$, and rinsed twice with PBS again. Next, DAPI staining solution was added to the covering scaffolds for $15 \mathrm{~min}$ in the dark, and were rinsed with PBS twice. Finally, cell images were obtained using a laser confocal microscope in the dark.

\section{RESULTS AND DISCUSSION XRD and FTIR Analyses}

Figure 1 shows the FTIR spectrum of HA, SA, CS and composite scaffolds. The peaks detected at 1,091, 1,022, 603, 563, and 960 $\mathrm{cm}^{-1}$ correspond to the $\mathrm{PO}_{4}^{3}$-band, indicating the presence of the HA phase (Cho et al., 2016; Wijesinghe et al., 2017). The spectrum

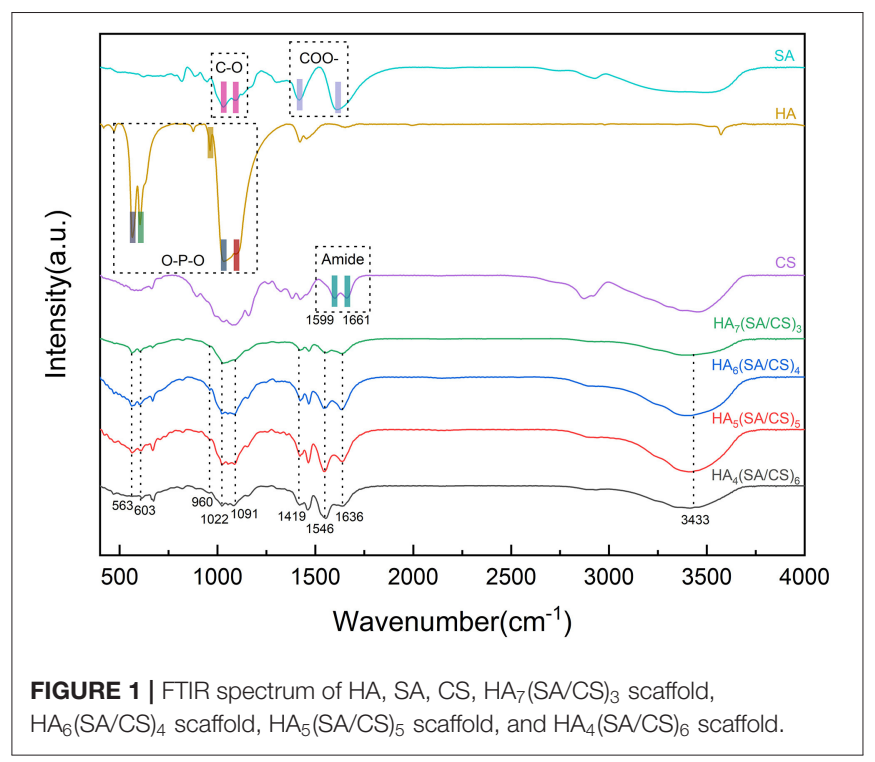

of unmodified CS showed characteristic peaks of Amide at 1,661 $\mathrm{cm}^{-1}\left(\mathrm{C}=\mathrm{O}\right.$ stretching) and $1,599 \mathrm{~cm}^{-1}(\mathrm{C}-\mathrm{N})$. The vibration peaks of CS at 1,661 and $1,599 \mathrm{~cm}^{-1}$ shift to 1,636 and 1,546 $\mathrm{cm}^{-1}$ in composite scaffolds. These changes may be attributed to the formation of hydrogen bonding between $\mathrm{OH}$ - groups in $\mathrm{HA}$ and $-\mathrm{C}=\mathrm{O}$ groups in CS. For the $\mathrm{SA}$, the absorption peaks at 1,029 and $1,095 \mathrm{~cm}^{-1}$ correspond to the stretching vibrations of the C-O. The bands at 1,612 and $1,419 \mathrm{~cm}^{-1}$ can be attributed to the symmetric and antisymmetric peaks of the COO- of SA (Sukhodub et al., 2016; You et al., 2019). The band at 3,433 $\mathrm{cm}^{-1}$ is due to the interaction between the amide group of CS and the hydroxyl group (Bi et al., 2019). The FTIR spectra of $\mathrm{HA}_{4}(\mathrm{SA} / \mathrm{CS})_{6}, \mathrm{HA}_{5}(\mathrm{SA} / \mathrm{CS})_{5}, \mathrm{HA}_{6}(\mathrm{SA} / \mathrm{CS})_{4}$, and $\mathrm{HA}_{7}(\mathrm{SA} / \mathrm{CS})_{3}$ tend to be consistent with each other.

To further determine the HA load and the hybrid scaffold, we conducted XRD experiments. The sharp diffraction peaks at $2 \theta$ $=25.8^{\circ}, 31.7^{\circ}, 32.9^{\circ}, 34.1^{\circ}$, and $45.3^{\circ}$ correspond to the faces (002), (211), (300), (202), and (203) of single crystalline HA, respectively. The results shown in Figure 2, demonstrate that the diffraction peak position of the composite scaffold group of each ratio is close to the diffraction peak position of the HA particles, and major peaks of HA are in a good agreement with those of HA standard data (JCPDS-09-0432) (Bi et al., 2019; You et al., 2019). The difference between the peaks may be due to the low crystallinity of HA caused by the synthesis of scaffolds and the different amount of HA in different scaffolds. It shows that during the preparation of the composite scaffold, the HA was successfully incorporated into the scaffolds. The CS acetic acid solution is slightly acidic, and in an acidic environment, the dissolved structure of HA changes. We constantly tried to adjust the $\mathrm{PH}$ method to avoid white flocs due to too fast adjustment of the $\mathrm{PH}$, and finally the mixture was adjusted to a neutral environment. The FTIR and XRD results confirmed that the HA crystal structure was not damaged, and that it was perfectly mixed inside the stent. 


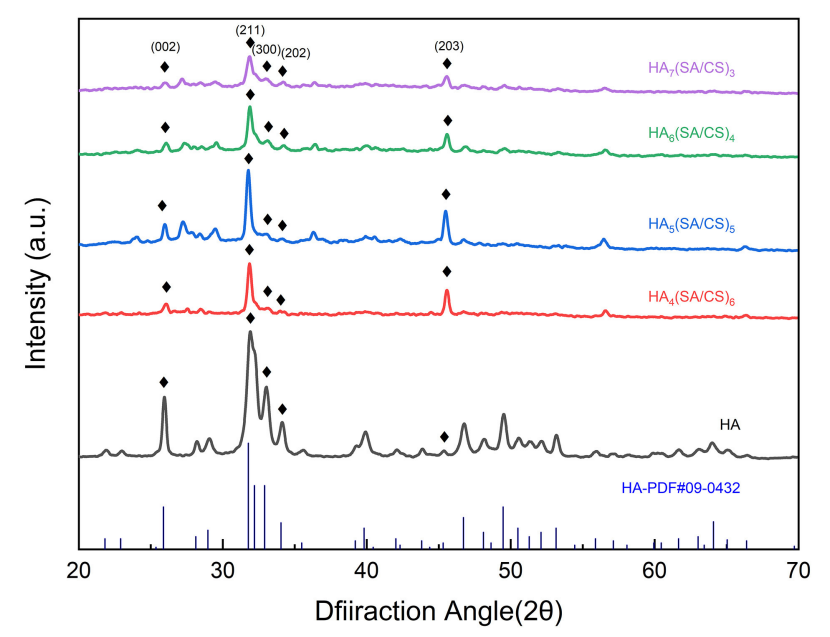

FIGURE 2 | XRD spectrum of $\mathrm{HA}, \mathrm{HA}_{7}(\mathrm{SA} / \mathrm{CS})_{3}$ scaffold, $\mathrm{HA}_{6}(\mathrm{SA} / \mathrm{CS})_{4}$ scaffold, $\mathrm{HA}_{5}(\mathrm{SA} / \mathrm{CS})_{5}$ scaffold, and $\mathrm{HA}_{4}(\mathrm{SA} / \mathrm{CS})_{6}$ scaffold.

\section{Scanning Electron Microscope (SEM) Analysis}

The interior of the stent is crucial for the "microenvironment." The size of the pores and the connectivity between them affect cell adhesion and crawling, the exchange between nutrients and metabolic waste, blood vessels, and bone regeneration (Peter et al., 2010; He et al., 2019). As shown in Figure 3, the pores in each group of stents are connected to each other in a meshlike structure. Observation under the microscope shows that as the increasing proportion of HA added, the pore size and pore number in the stent become negatively correlated. The $\mathrm{HA}_{4}(\mathrm{SA} / \mathrm{CS})_{6}$ sets of stents are loose and porous, and the pore size can be up to $500 \mu \mathrm{m}$, whereas the $\mathrm{HA}_{5}(\mathrm{SA} / \mathrm{CS})_{5}$ and $\mathrm{HA}_{6}(\mathrm{SA} / \mathrm{CS})_{4}$ sets of stents have an internal pore size of 100 $300 \mu \mathrm{m}$. The $\mathrm{HA}_{7}(\mathrm{SA} / \mathrm{CS})_{3}$ sets of stents are relatively dense and the pore size is only about $100 \mu \mathrm{m}$. The difference in pore size among the four groups of stents is obvious. Hence the stents that are beneficial to bone tissue regeneration can be selected based on pore size. Studies have shown that scaffolds with a pore size of 100-200 $\mu \mathrm{m}$ have obvious osteogenic effects in vitro (Brennan et al., 2019), and stents with a pore size of about $133 \mu \mathrm{m}$ are conducive to the production of extracellular matrix in vitro (Lutzweiler et al., 2019). However, studies by $\mathrm{Oh}$ et al. (2007) have shown that in in vivo experiments scaffolds of $290-310 \mu \mathrm{m}$ are more suitable for the formation of new bones. In addition, Roosa et al. (2010) also found that scaffolds with pore diameter of $350-800 \mu \mathrm{m}$ can show bone tissue growing outside the scaffold, but scaffolds with pore diameter $<350 \mu \mathrm{m}$ show obvious in stent bone formation.

\section{Contraction Percentage Test}

In stents made of multiple phases, CS can reduce the shrinkage performance of the stent (Peng et al., 2016), which is beneficial to the formation of the stent and has the ability to prevent deformation. In the experimental group, the contraction percentage of the stent was positively correlated with the specific gravity of HA, and its contraction percentage performance was more obvious in the vertical height. HA further compresses the space in the height direction of the stent due to its large specific gravity. In Figure $\mathbf{4 A}$, in the $\mathrm{HA}_{4}(\mathrm{SA} / \mathrm{CS})_{6}$ and $\mathrm{HA}_{5}(\mathrm{SA} / \mathrm{CS})_{5}$ stent groups, the contraction percentage was significantly lower than that of the control group. However, as the proportion of HA continues to increase, it exerts a more significant effect on the overall stability of the interior of the stent. It plays a role of "load-bearing wall" in maintaining the height of the scaffold, and finally shows higher dimensional stability in the high proportion group. The gravity of hydroxyapatite determines the anisotropy of scaffold contraction.

\section{Swelling Behavior}

HA has a large specific gravity and strong hydrophilicity (Januariyasa et al., 2020). When the proportion of HA in the stent is small, the hydrophilic capacity of the stent can be increased, and finally the stent shows water swelling. However, when the specific gravity of medium HA gradually increases, the gravity factor is more important than the hydrophilic factor for the stent's water absorption and swelling ability. This is demonstrated in Figure 4B, in which a gradual decrease of the water absorption and swelling ability of the stent is observed. In the scanning electron micrograph, HA is uniformly dispersed in the scaffold, and after crosslinking, it binds firmly with SA and CS. Slight water absorption and swelling can fill the small gap between the scaffold and the bone defect, which is conducive to the adhesion and migration of cells at the interface between the scaffold and the bone tissue, and ensures that the cells enter the scaffold to form bone inside it.

\section{Mechanical Properties}

Figure 4C shows the elastic modulus of the composite scaffold with different weight ratios of HA/SA/CS. It can be seen that after adding HA, the mechanical strength of the composite scaffold is positively correlated with the specific gravity of the HA. This is consistent with other reports (Chen et al., 2019; Mondal et al., 2020). The mechanical strength of $\mathrm{HA}_{7}(\mathrm{SA} / \mathrm{CS})_{3}$ stent group was more than 6 times that of $\mathrm{HA}_{0}(\mathrm{SA} / \mathrm{CS})_{10}$. The scanning electron microscope showed that the interior of the stent with the high proportion of HA is denser. This is because HA can be embedded in the wall of the stent hole, which increases the strength of the composite stent, but as the proportion of HA increases, the proportion of SA and CS decreases, and the brittleness of the composite stent increases significantly.

\section{Degradation Studies}

The degradation rate of the scaffold at the bone defect should ideally match the speed of new bone formation. The rate of bone tissue regeneration is much slower than that of soft tissue regeneration (Peñarrocha-Diago et al., 2020). Thus, if the scaffold degrades rapidly during the early stage of bone formation, it will not provide a good barrier for bone tissue regeneration, and this will ultimately lead to soft tissue expansion into the bone defect, which is not conducive to bone organizational regeneration. As shown in Figure 4D, the degradation rate of the $\mathrm{HA}_{4}(\mathrm{SA} / \mathrm{CS})_{6}$ 

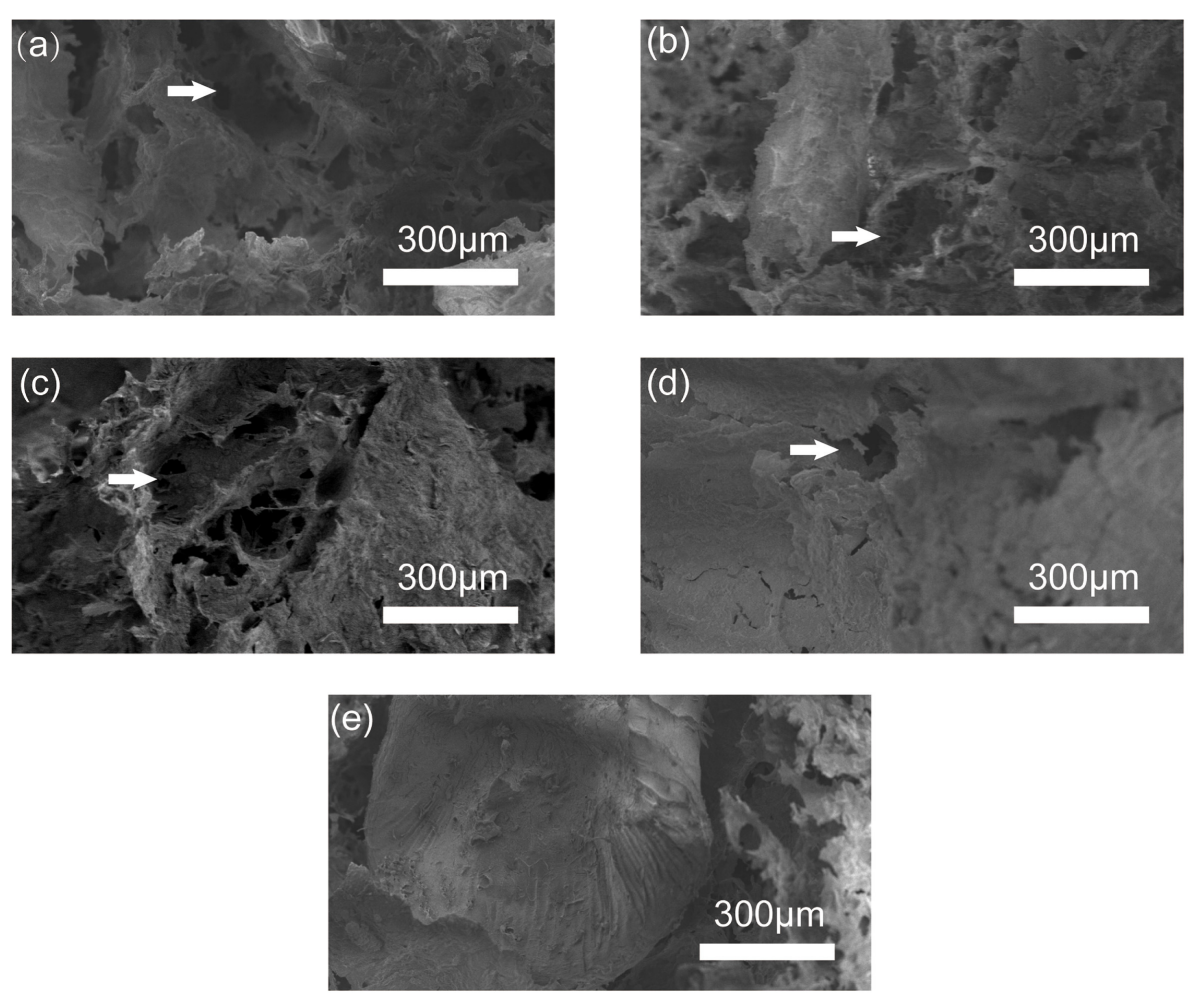

FIGURE 3 | SEM image of (a) $\mathrm{HA}_{4}(\mathrm{SA} / C S)_{6}$ scaffold, (b) $\mathrm{HA}_{5}(\mathrm{SA} / C S)_{5}$ scaffold, (c) $\mathrm{HA}_{6}(\mathrm{SA} / \mathrm{CS})_{4}$ scaffold, (d) $\mathrm{HA}_{7}(\mathrm{SA} / \mathrm{CS})_{3}$ scaffold, and (e) microsphere inside the scaffold.
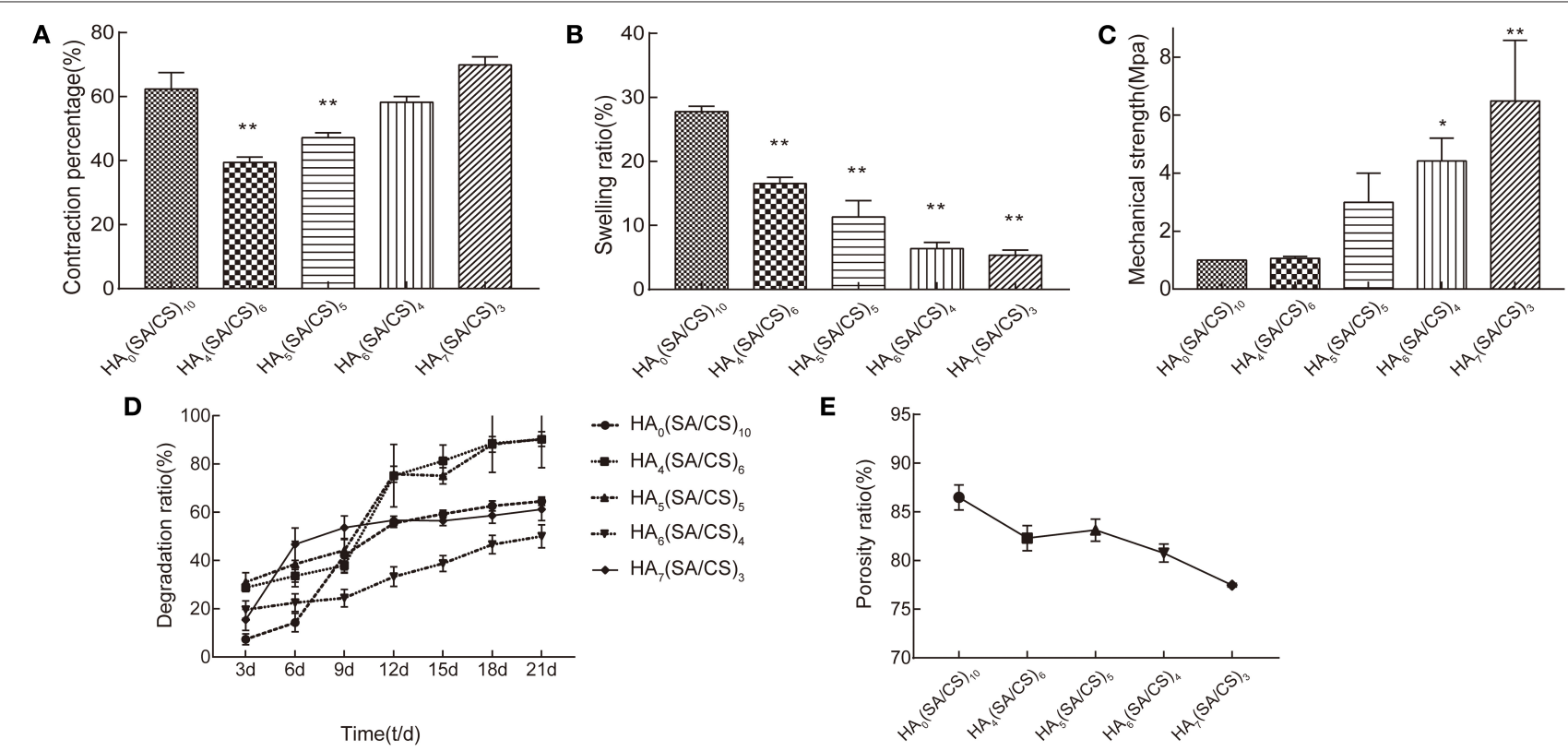

FIGURE 4 | (A) Contraction percentage, (B) swelling ratio, (C) mechanical strength, (D) degradation ratio, (E) porosity ratio of $\mathrm{HA}_{0}(\mathrm{SA} / \mathrm{CS})_{10} \mathrm{Scaffold}_{1} \mathrm{HA}_{4}(\mathrm{SA} / \mathrm{CS})_{6}$ scaffold, $\mathrm{HA}_{5}(\mathrm{SA} / \mathrm{CS})_{5}$ scaffold, $\mathrm{HA}_{6}(\mathrm{SA} / \mathrm{CS})_{4}$ scaffold, and $\mathrm{HA}_{7}(\mathrm{SA} / \mathrm{CS})_{3}$ scaffold. ${ }^{*} p<0.05,{ }^{* *} p<0.01$.

and $\mathrm{HA}_{5}(\mathrm{SA} / \mathrm{CS})_{5}$ scaffold group was the fastest, reaching a degradation rate of $90 \%$ on day 21 , whereas the degradation rate of the $\mathrm{HA}_{6}(\mathrm{SA} / \mathrm{CS})_{4}$ scaffold group was relatively stable, being $50.01 \%$ on day 21 . In $\mathrm{HA}_{7}(\mathrm{SA} / \mathrm{CS})_{3}$ scaffold group, the degradation amount accounted for $31.29 \%$ of the total stent from the $3 \mathrm{rd}$ to the 6 th day, and then the degradation tended 
to be gentle. This occurs because the water-swelling expansion force of the slow-release microspheres encased in the scaffold is much greater than that in $\mathrm{HA}_{7}(\mathrm{SA} / \mathrm{CS})_{3}$. The specific gravity of sodium alginate chitosan in $\mathrm{HA}_{7}(\mathrm{SA} / \mathrm{CS})_{3}$ scaffold group was lower than that in $\mathrm{HA}_{6}(\mathrm{SA} / \mathrm{CS})_{4}$ scaffold group, which led to the stent rupture from the inside, and a part of sustainedrelease microspheres were separated from the stent, resulting in a significant reduction in weight. The microspheres detached from the inside of the support, resulting in a significant reduction in weight.

\section{Porosity Measurement}

A higher porosity can ensure a higher material exchange capacity inside the stent, which is conducive to maintaining the steady state of the "osteogenesis microenvironment" (Shi et al., 2007). The increase of HA compresses the volume of the scaffold at the height level, resulting in a decrease in the porosity of the scaffold in the experimental group. Furthermore, the crosslinking of the calcium chloride solution establishes a large number of connections between SA and CS (Heo et al., 2017). The stent pores are further reduced and stabilized. As shown in Figure $4 \mathrm{E}$, the porosity of the $\mathrm{HA}_{4}(\mathrm{SA} / \mathrm{CS})_{6}, \mathrm{HA}_{5}(\mathrm{SA} / \mathrm{CS})_{5}$, and $\mathrm{HA}_{6}(\mathrm{SA} / \mathrm{CS})_{4}$ scaffold groups can reach $80 \%$, and the porosity of the $\mathrm{HA}_{7}(\mathrm{SA} / \mathrm{CS})_{3}$ scaffold group can decrease to $77.47 \%$. Therefore, the $\mathrm{HA}_{5}(\mathrm{SA} / \mathrm{CS})_{5}$ and $\mathrm{HA}_{6}(\mathrm{SA} / \mathrm{CS})_{4}$ sets of scaffolds are more conducive to the formation of bone tissue inside them.

\section{Scaffold Drug Release Ability}

The composite stent prepared in this experiment carried two drugs, VEGF and VAN. VEGF was wrapped in internal microspheres and VAN was carried in an external stent. As shown in Figure 5, the release curve of the two different stents was not significantly different due to the uniform mixing of the VAN in the external stent. Furthermore, the released amount reached $80 \%$ on day 4 , demonstrating that a higher concentration of VAN is maintained during early bone defect regeneration, inhibiting the growth of bacteria in the bone defect, and providing a bacteria-free environment during the early stages of bone regeneration (Zhou et al., 2018; Wei et al., 2019). In the early stage of drug release, due to the presence of the SA-CS block layer outside the slow-release microspheres inside the stent, the early release of VEGF was small. As the stent degraded, the VEGF inside the microspheres was gradually released. The release of VEGF in the $\mathrm{HA}_{6}(\mathrm{SA} / \mathrm{CS})_{4} @ \mathrm{VEGF} / \mathrm{VAN}$ stent was greater than that of the $\mathrm{HA}_{0}(\mathrm{SA} / \mathrm{CS})_{10} @ \mathrm{VEGF} / \mathrm{VAN}$ stent from day 6 to day 9 , which is related to the good hydrophilicity of HA (Babaei et al., 2019). Since day 9, the release of VEGF tended to be flat.

\section{Detection of Stent Antibacterial Properties}

The quantitative and qualitative antibacterial experiments showed that the composite stent had good antibacterial properties. As shown in Figure 6, the $\mathrm{HA}_{6}(\mathrm{SA} / \mathrm{CS})_{4} @ V E G F / V A N$ scaffold and the $\mathrm{HA}_{0}(\mathrm{SA} / \mathrm{CS})_{10} @ \mathrm{VEGF} / \mathrm{VAN}$ scaffold showed obvious antibacterial ability. Because of the lack of effective antibacterial ingredients, the $\mathrm{HA}_{6}(\mathrm{SA} / \mathrm{CS})_{4} @ \mathrm{VEGF}$ and $\mathrm{HA}_{0}(\mathrm{SA} / \mathrm{CS})_{10} @ \mathrm{VEGF}$ scaffolds showed no obvious growth inhibitory effect on $S$. aureus. Obviously, on the first day, the VAN (+) stent showed a good antibacterial performance, and maintained a stable antibacterial effect on days 3 and 5. As shown in the figure, after 1, 3, and 5 days of incubation, a clear inhibitory ring was formed around the $\mathrm{HA}_{6}(\mathrm{SA} / \mathrm{CS})_{4} @ \mathrm{VEGF} / \mathrm{VAN}$ and $\mathrm{HA}_{0}(\mathrm{SA} / \mathrm{CS})_{10} @ \mathrm{VEGF} / \mathrm{VAN}$ scaffolds, which indicates that the VAN released by the scaffold has biological activity. Each antibacterial ring uses a vernier caliper to measure the diameter every $60^{\circ}$, that is, each antibacterial ring is measured three times. The results show that the VAN $(+)$ bracket has a good antibacterial property. The release of active VAN could inhibit the bacteria in the bone defect and prevent the slow or even poor healing of bone tissue caused by the presence of bacteria (Avani et al., 2019; Wei et al., 2019).

\section{BMSCs Morphology and Growth Status}

After $72 \mathrm{~h}$ of standing culture, several clone colonies of primary BMSCs were seen, which primarily composed of astrocytes, with a small number of spindle cells, and a large number of blood cells and other miscellaneous cells, as shown in Figure 7a. Though continuous passage, the astrocytes were elongated, mainly fusiform, arranged in a vortex-like growth, with fewer heterocells and higher purity, as shown in Figures $7 \mathbf{b}, \mathbf{c}$.

\section{BMSCs Differentiation Test}

After 11 days of osteoinduction, alizarin red staining showed obvious calcium nodules, as shown in Figure 7d. After 7 days of induction of fat formation, tiny lipid droplets could be seen in the cells under the microscope. With the extension of the induction time, the lipid droplets gradually became larger and merged. Eleven days later, oil red O staining showed obvious lipid droplets, as shown in Figure 7e.

\section{Cytotoxicity Test}

Figure $7 \mathbf{f}$ shows that the cells were co-cultured with complete L-DMEM and scaffold extraction separately. On days 1, 3, 5, and 7 , the cells in the blank group, $\mathrm{HA}_{0}(\mathrm{SA} / \mathrm{CS})_{10} @ \mathrm{VEGF} / \mathrm{VAN}$ group, and $\mathrm{HA}_{6}(\mathrm{SA} / \mathrm{CS})_{4} @ \mathrm{VEGF} / \mathrm{VAN}$ group all showed good proliferation ability. There was no statistically significant difference in cell proliferation among the three groups. Compared with the blank, the $\mathrm{HA}_{0}(\mathrm{SA} / \mathrm{CS})_{10} @ \mathrm{VEGF} / \mathrm{VAN}$ and $\mathrm{HA}_{6}(\mathrm{SA} / \mathrm{CS})_{4} @ V E G F / V A N$ groups were not cytotoxic, which was conducive to cell adhesion in the scaffold.

\section{Effect of the HA/SA/CS Scaffold on Osteogenic Differentiation of BMSCs}

\section{Calcium Ion Release}

On days $1,5,7$, and 14 , the $\mathrm{HA}_{6}(\mathrm{SA} / \mathrm{CS})_{4} @$ VEGF/VAN and $\mathrm{HA}_{0}(\mathrm{SA} / \mathrm{CS})_{10} @ V E G F / V A N$ scaffolds released calcium ions in PBS as shown in Figure $7 \mathrm{~g}$. Within 14 days, the two groups of stents continued to release calcium ions, but there was no statistical difference in the released amount. With the degradation, the release of calcium ion in hydroxyapatite is relatively slow (Witek et al., 2017). In addition, $\mathrm{CaCl}_{2}$ solution was used for cross-linking during the preparation of scaffolds, which made sodium alginate become calcium alginate. Over time, calcium ion release in calcium alginate was relatively large, so 

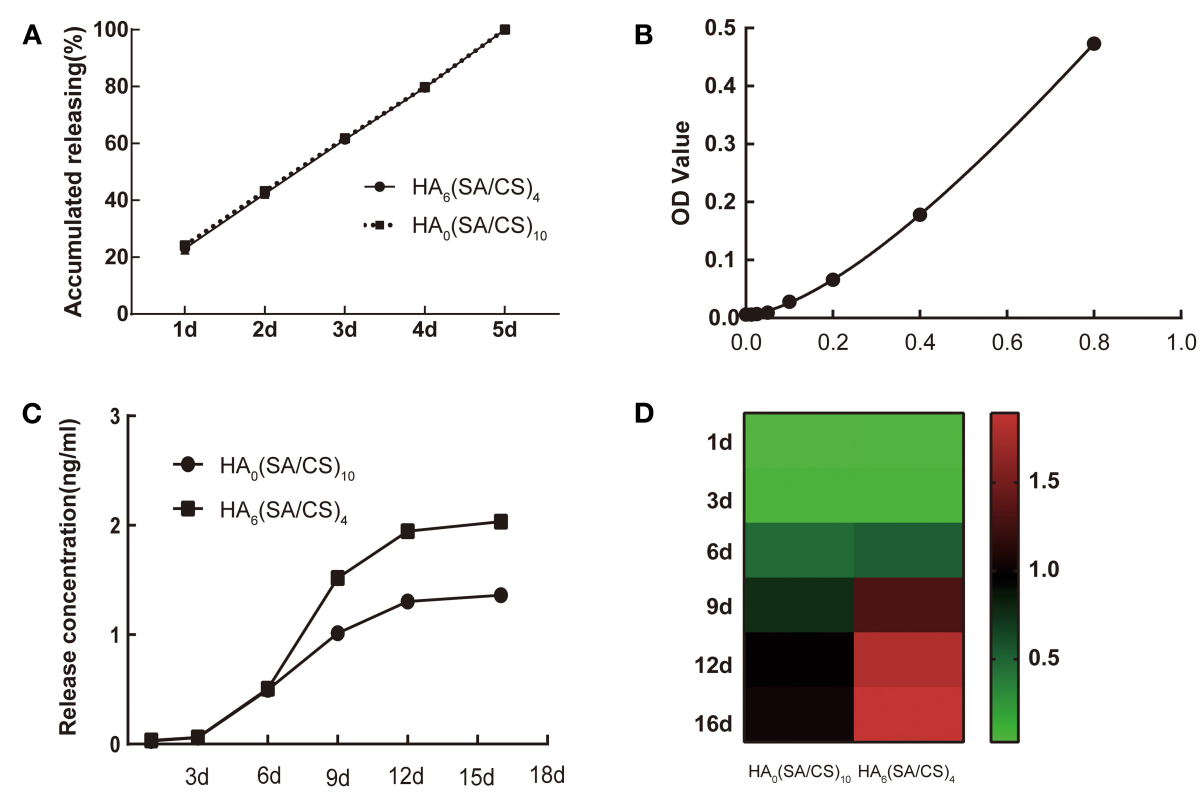

FIGURE 5 | (A) The release curve of VAN on HA (SA/CS $_{10}$ scaffold and HA 6 (SA/CS) 4 scaffold. (B) A standard ELISA curve for VEGF. (C) The VEGF release curves of $\mathrm{HA}_{0}(\mathrm{SA} / \mathrm{CS})_{10}$ scaffold and $\mathrm{HA}_{6}(\mathrm{SA} / \mathrm{CS})_{4}$ scaffold. (D) The VEGF release of heat map of $\mathrm{HA}_{0}(\mathrm{SA} / \mathrm{CS})_{10}$ scaffold and $\mathrm{HA} \mathrm{A}_{6}(\mathrm{SA} / \mathrm{CS})_{4}$ scaffold.

A

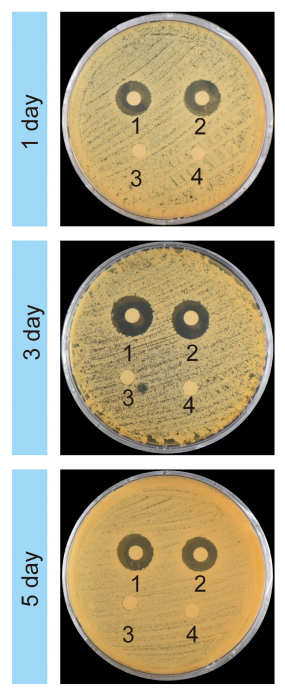

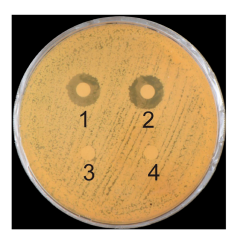
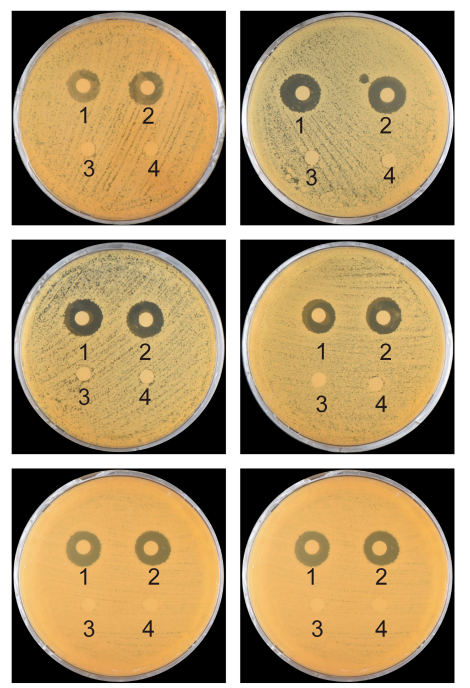
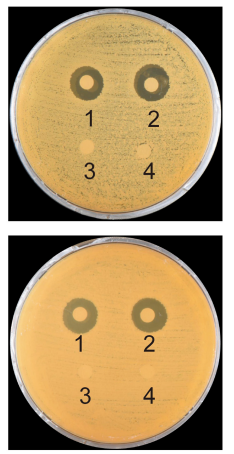

B
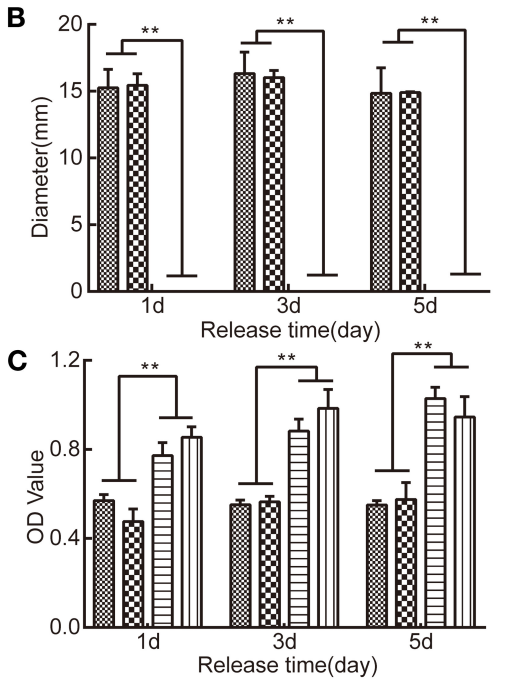

冈 $\mathrm{HA}_{6}(\mathrm{SA} / \mathrm{CS})_{4} @ V E G F / V A N$

$\infty \mathrm{HA}_{0}(\mathrm{SA} / \mathrm{CS})_{10} @ \mathrm{VEGF} / \mathrm{VAN}$

$\boxminus \mathrm{HA}_{6}(\mathrm{SA} / \mathrm{CS})_{4}$

皿 $\mathrm{HA}_{0}(\mathrm{SA} / \mathrm{CS})_{10}$

FIGURE 6 | (A) Bacterial growth inhibition on agar plates after 1d, 3d, and 5d. (B) The diameter of bacteriostatic rings of the four groups of scaffolds cultured for $1 d$, $3 d$, and $5 d$. (C) The OD value of the bacterial liquid medium after the scaffold and the bacterial liquid medium were co-cultured for 1d, 3d, and $5 d$. Numbers $1-4$ indicate $\mathrm{HA}_{0}(\mathrm{SA} / \mathrm{CS})_{10} @$ VEGFNAN scaffold, $\mathrm{HA}_{6}(\mathrm{SA} / \mathrm{CS})_{4} @$ VEGFNAN scaffold, $\mathrm{HA}_{0}(\mathrm{SA} / \mathrm{CS})_{10}$ scaffold, and $\mathrm{HA}_{6}(\mathrm{SA} / \mathrm{CS})_{4}$ scaffold. ${ }^{* *} p<0.01$.

there was no significant difference in calcium ion release between the two groups.

Calcium ions play an important role in the process of bone reconstruction. A low extracellular concentration of calcium ions $(2-4 \mathrm{~mm})$ can affect the calcium-sensitive receptor of osteoblasts, leading to the activation of the intracellular mechanism, increasing the expression of insulin-like growth factor, and promoting the survival and proliferation of osteoblasts. Furthermore, a moderate concentration of calcium ion $(6-8 \mathrm{~mm})$ can promote the differentiation of osteoblasts. When the concentration of calcium ions is higher than $10 \mathrm{~mm}$, it will affect the health of osteoblasts (Maeno et al., 2005; Shie and Ding, 2013).

\section{Degree of Mineralization of the Extracellular Matrix}

After 11 days of osteogenic induction, the alizarin red staining results were shown in Figures $\mathbf{8 a}-\mathbf{c}$. The three groups had different degrees of calcium salt deposition. The number of 

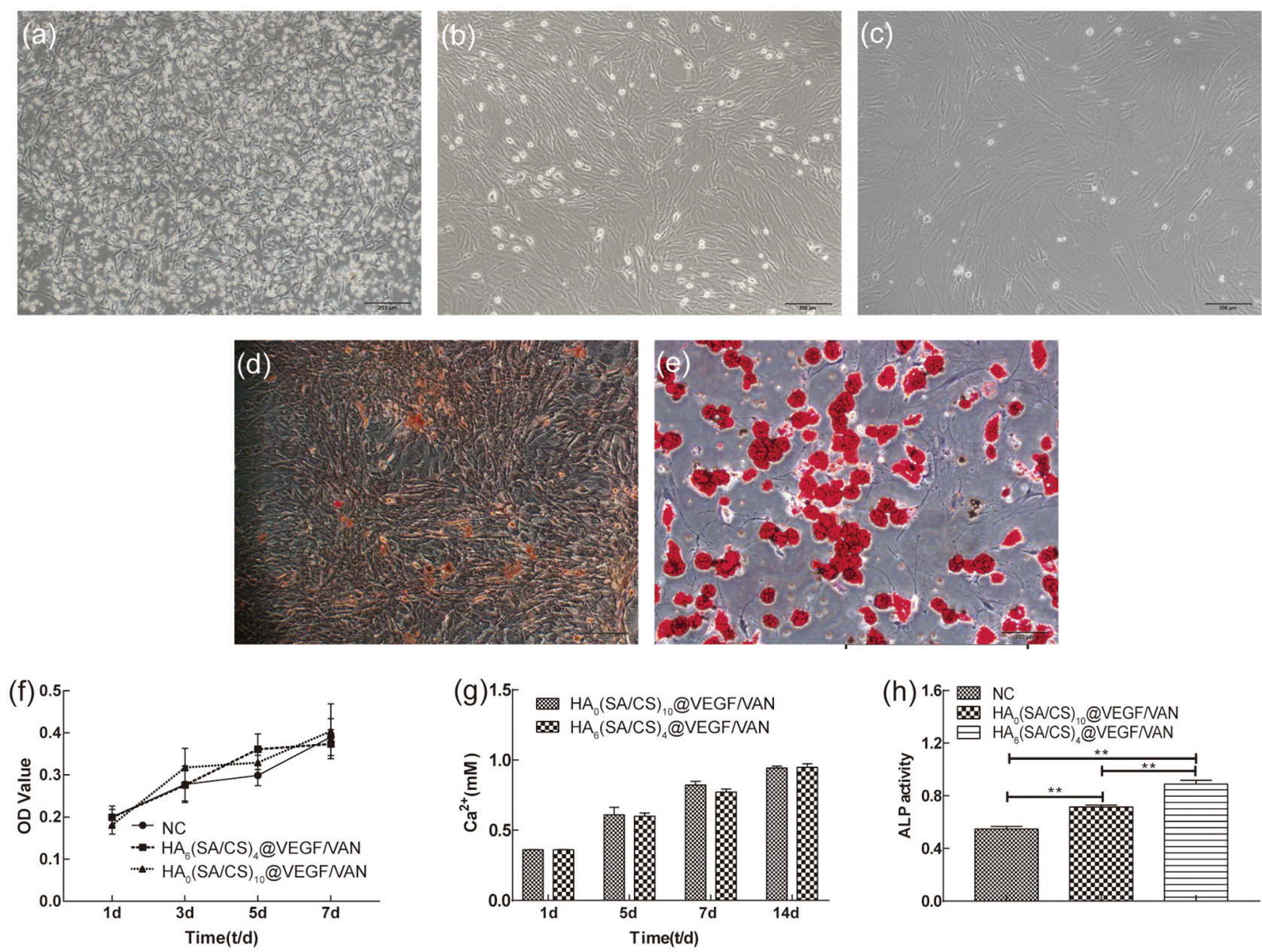

FIGURE 7 | (a) Morphology of primary BMSCs. (b) Morphology of first generation BMSCs. (c) Morphology of third generation BMSCs. (d) Alizarin red staining

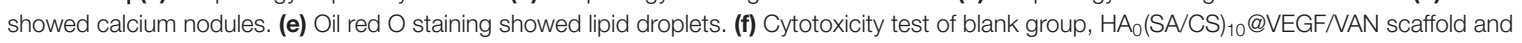
$\mathrm{HA}_{6}(\mathrm{SA} / \mathrm{CS})_{4} @ \mathrm{VEGF}$ NAN scaffold. (g) $\mathrm{Ca}^{2+}$ released from the scaffolds. (h) Results of ALP activity measurement in each group. ${ }^{* \star} p<0.01$.

scaffolds was more than that of the blank group, and the $\mathrm{HA}_{6}(\mathrm{SA} / \mathrm{CS})_{4} @ \mathrm{VEGF} / \mathrm{VAN}$ group was obviously more than $\mathrm{HA}_{0}(\mathrm{SA} / \mathrm{CS})_{10} @ \mathrm{VEGF} / \mathrm{VAN}$ group.

\section{Cell ALP Activity and Expression Levels}

The results of ALP activity were shown in Figure 8. The staining results showed that the staining in Figure 8d was the lightest, while that in Figure 8 f was the strongest. The degree of staining directly reflected the level of ALP expression, indicating that the expression level of the blank group was the lowest and the expression level of the $\mathrm{HA}_{6}(\mathrm{SA} / \mathrm{CS})_{4} @ \mathrm{VEGF} / \mathrm{VAN}$ group was the highest. The results of ALP semi-quantitative analysis, in Figure $7 \mathbf{h}$, showed that the DEA enzyme activity of the ALP in the scaffold groups was significantly higher than that in the blank group. Compared with the $\mathrm{HA}_{0}(\mathrm{SA} / \mathrm{CS})_{10} @ \mathrm{VEGF} / \mathrm{VAN}$ group, the $\mathrm{HA}_{6}(\mathrm{SA} / \mathrm{CS})_{4} @ V E G F / V A N$ group had a statistically higher expression of ALP.

\section{Cell Adhesion on the Scaffold}

The results of layered scanning of the stent material were shown in Figures 9a,b. The round blue-stained structures were the nuclei, which indicated that the cells attached successfully to the three-dimensional structure of the $\mathrm{HA}_{0}(\mathrm{SA} / \mathrm{CS})_{10} @ \mathrm{VEGF} / \mathrm{VAN}$ and $\mathrm{HA}_{6}(\mathrm{SA} / \mathrm{CS})_{4} @ \mathrm{VEGF} / \mathrm{VAN}$ scaffolds. As for the number of cells, cells adhered inside the $\mathrm{HA}_{6}(\mathrm{SA} / \mathrm{CS})_{4} @ \mathrm{VEGF} / \mathrm{VAN}$ scaffold were significantly higher than that of $\mathrm{HA}_{0}(\mathrm{SA} / \mathrm{CS})_{10} @$ VEGF/VAN scaffold.

\section{Transcription Levels of Osteogenesis Related Genes}

As shown in Figure 9c, compared with the blank control group, the expression levels of BMP2 and OPN in the $\mathrm{HA}_{0}(\mathrm{SA} / \mathrm{CS})_{10} @ \mathrm{VEGF} / \mathrm{VAN}$ group were statistically different, while the expression levels of ALP, BMP2, OPN, and Runx2 in the $\mathrm{HA}_{6}(\mathrm{SA} / \mathrm{CS})_{4} @ \mathrm{VEGF} / \mathrm{VAN}$ group were different. The expression levels of ALP, BMP2, OPN and Runx2 were compared between the $\mathrm{HA}_{0}(\mathrm{SA} / \mathrm{CS})_{10} @ \mathrm{VEGF} / \mathrm{VAN}$ and $\mathrm{HA}_{6}(\mathrm{SA} / \mathrm{CS})_{4} @ \mathrm{VEGF} / \mathrm{VAN}$ groups. ALP is a marker of 

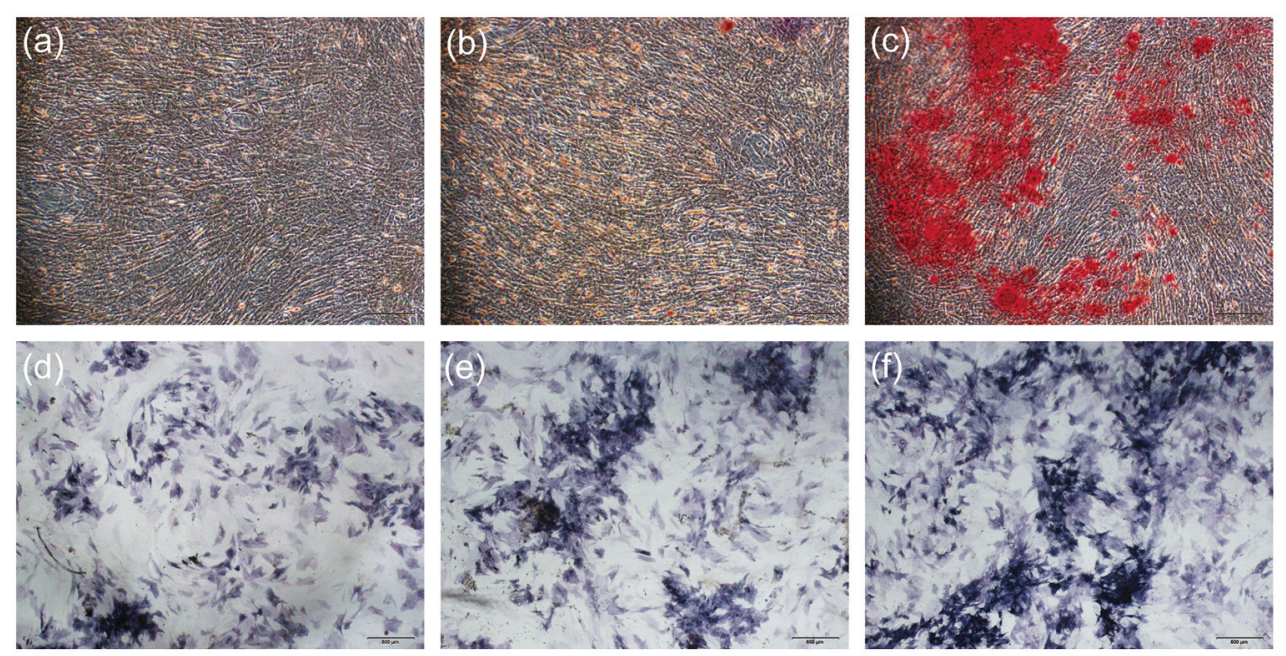

FIGURE 8 | (a) Alizarin red staining of blank group. (b) Alizarin red staining of HA (SA $_{0}$ CS) ${ }_{10} @$ VEGFNAN scaffold. (c) Alizarin red staining of HA ${ }_{6}(\mathrm{SA} / \mathrm{CS})_{4} @ \mathrm{VEGFNAN}$ scaffold. (d) Results of intracellular ALP activity expression in blank group. (e) Results of intracellular ALP activity expression in HA 0 (SAVCS) ${ }_{10} @$ VEGFNAN scaffold. (f) Results of intracellular ALP activity expression in $\mathrm{HA}_{6}(\mathrm{SA} / \mathrm{CS})_{4} @$ VEGFNAN scaffold.
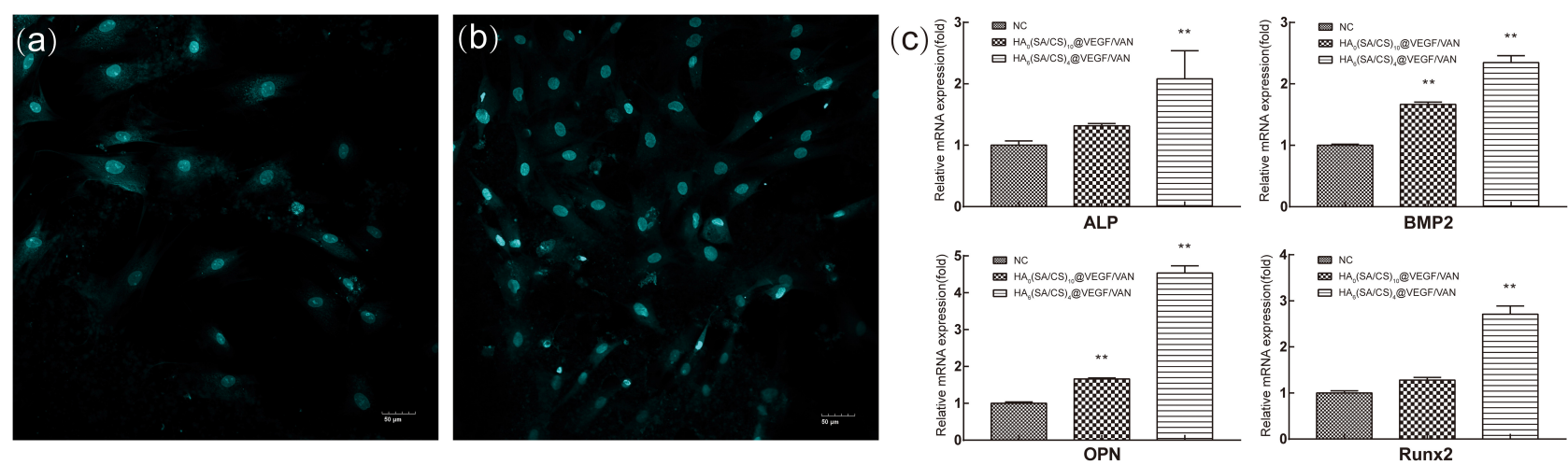

FIGURE 9 | (a) Laser confocal image of cells adhesion on HA $\left(\right.$ SAVCS) ${ }_{10} @$ VEGFNAN scaffold. (b) Laser confocal image of cells adhesion on. (c) Real-time PCR results of osteogenesis-related gene in each group. ${ }^{* \star} p<0.01$.

osteoblasts in the early stage of maturation, while Runx2 is another marker of osteoblasts in the early stage of maturation, which participates in all stages of stem cell differentiation into mature osteoblasts (Bruderer et al., 2014). OPN is a marker of the final stage of osteoblast differentiation, which plays a role in the mineralization of the extracellular matrix and the adhesion between osteoblasts and the matrix. BMP 2 can regulate ALP, Runx2, OPN, and other osteoblasts through different signal pathways. The orderly expression of related genes ALP, Runx2, OCN, and BMP2 is involved in the process of bone formation and bone metabolism, and their transcriptional expression level reflects to a great extent the degree of osteogenic differentiation of BMSCs. Real-time PCR results showed that osteogenic genes in BMSCs were activated and expressed in varying degrees after osteogenic induction. Compared with $\mathrm{HA}_{0}(\mathrm{SA} / \mathrm{CS})_{10} @ \mathrm{VEGF} / \mathrm{VAN}$ scaffolds, $\mathrm{HA}_{6}(\mathrm{SA} / \mathrm{CS})_{4} @ \mathrm{VEGF} / \mathrm{VAN}$ scaffolds had more significant effects on ALP, BMP2, OPN, and Runx2 expression.

\section{CONCLUSION}

We successfully prepared and used a SA/CS/HA composite scaffold loaded with VEGF and VAN. By synthesizing composite scaffolds with different ratios and conducting performance tests, we selected the composite scaffolds with the best performance. Hence, the chronological release of the two drugs and the mechanical strength of the scaffold are guaranteed. The composite scaffold has good performance and provides a new strategy for repairing bone defects in infected areas.

\section{DATA AVAILABILITY STATEMENT}

The raw data supporting the conclusions of this article will be made available by the authors, without undue reservation. 


\section{ETHICS STATEMENT}

The animal study was reviewed and approved by Jilin University Stomatology School Animal Care and Use Committee.

\section{AUTHOR CONTRIBUTIONS}

BoW and DL designed the work. DL and ZL wrote the manuscript. DL, JZ, LL, and XS carried out the experiments. DL, $\mathrm{BiW}$, and NY carried out the literature search, data acquisition, and data analysis. All authors have read and approved the content of the manuscript.

\section{FUNDING}

This study was supported by the Key Scientific and Technological Research and Development Projects (20180201056YY), and the Medical and Health Project (20190304032YY) of the Science and Technology Department of Jilin province of China, and Graduate Innovation Fund of Jilin University (101832018C082).

\section{REFERENCES}

Arafa, M. G., Mousa, H. A., and Afifi, N. N. (2020). Preparation of PLGAchitosan based nanocarriers for enhancing antibacterial effect of ciprofloxacin in root canal infection. Drug Deliv. 27, 26-39. doi: 10.1080/10717544.2019.17 01140

Arthur, A., and Gronthos, S. (2020). Clinical application of bone marrow mesenchymal stem/stromal cells to repair skeletal tissue. Int. J. Mol. Sci. 21:9759. doi: 10.3390/ijms212 49759

Avani, F., Damoogh, S., Mottaghitalab, F., Karkhaneh, A., and Farokhi, M. (2019). Vancomycin loaded halloysite nanotubes embedded in silk fibroin hydrogel applicable for bone tissue engineering. Int. J. Polym. Mater. Poly. 69, 32-43. doi: 10.1080/00914037.2019.16 16201

Babaei, M., Ghaee, A., and Nourmohammadi, J. (2019). Poly (sodium 4-styrene sulfonate)-modified hydroxyapatite nanoparticles in zein-based scaffold as a drug carrier for vancomycin. Mater. Sci. Eng. C Mater. Biol. Appl. 100, 874-885. doi: 10.1016/j.msec.2019.03.055

Bi, Y. G., Lin, Z. T., and Deng, S. T. (2019). Fabrication and characterization of hydroxyapatite/sodium alginate/chitosan composite microspheres for drug delivery and bone tissue engineering. Mater. Sci. Eng. C Mater. Biol. Appl. 100, 576-583. doi: 10.1016/j.msec.2019.03.040

Brennan, C., Eichholz, K., and Hoey, D. (2019). The effect of pore size within fibrous scaffolds fabricated using melt electrowriting on human bone marrow stem cell osteogenesis. Biomed. Mater. 14:065016. doi: 10.1088/1748-605X/ab49f2

Bruderer, M., Richards, R. G., Alini, M., and Stoddart, M. J. (2014). Role and regulation of RUNX2 in osteogenesis. Eur. Cell. Mater. 28, 269-286. doi: 10.22203/eCM.v028a19

Chen, C. Y., Chen, C. C., Wang, C. Y., Lee, A. K., Yeh, C. L., and Lin, C. P. (2020). Assessment of the release of vascular endothelial growth factor from 3D-printed poly-epsilon-caprolactone/hydroxyapatite/calcium sulfate scaffold with enhanced osteogenic capacity. Polymers 12:1455. doi: $10.3390 /$ polym 12071455

Chen, S., Shi, Y., Zhang, X., and Ma, J. (2019). 3D printed hydroxyapatite composite scaffolds with enhanced mechanical properties. Ceram. Int. 45, 10991-10996. doi: 10.1016/j.ceramint.2019.02.182

Cheng, T., Qu, H., Zhang, G., and Zhang, X. (2018). Osteogenic and antibacterial properties of vancomycin-laden mesoporous bioglass/PLGA composite scaffolds for bone regeneration in infected bone defects. Artif. Cells Nanomed. Biotechnol. 46, 1935-1947. doi: 10.1080/21691401.2017.13 96997

Cho, J. S., Lee, J. C., and Rhee, S. H. (2016). Effect of precursor concentration and spray pyrolysis temperature upon hydroxyapatite particle size and density. J. Biomed. Mater. Res. Part B Appl. Biomater. 104, 422-430. doi: 10.1002/jbm.b.33406

De Vriese, A. S., and Vandecasteele, S. J. (2014). Vancomycin: the tale of the vanquisher and the pyrrhic victory. Perit. Dial. Int. 34, 154-161. doi: $10.3747 /$ pdi.2014.00001
Garcia, J. R., Clark, A. Y., and Garcia, A. J. (2016). Integrin-specific hydrogels functionalized with VEGF for vascularization and bone regeneration of critical-size bone defects. J. Biomed. Mater. Res. A 104, 889-900. doi: $10.1002 /$ jbm.a.35626

Garcia-Gonzalez, C. A., Barros, J., Rey-Rico, A., Redondo, P., Gomez-Amoza, J. L., Concheiro, A., et al. (2018). Antimicrobial properties and osteogenicity of vancomycin-loaded synthetic scaffolds obtained by supercritical foaming. ACS Appl. Mater. Interfaces 10, 3349-3360. doi: 10.1021/acsami.7b 17375

Gu, F., Amsden, B., and Neufeld, R. (2004). Sustained delivery of vascular endothelial growth factor with alginate beads. J. Control. Release 96, 463-472. doi: 10.1016/j.jconrel.2004.02.021

Hao, Z., Song, Z., Huang, J., Huang, K., Panetta, A., Gu, Z., et al. (2017). The scaffold microenvironment for stem cell based bone tissue engineering. Biomater. Sci. 5, 1382-1392. doi: 10.1039/C7BM 00146K

Hashimoto, Y., Nishida, Y., Takahashi, S., Nakamura, H., Mera, H., Kashiwa, K., et al. (2019). Transplantation of autologous bone marrow-derived mesenchymal stem cells under arthroscopic surgery with microfracture versus microfracture alone for articular cartilage lesions in the knee: a multicenter prospective randomized control clinical trial. Regen. Ther. 11, 106-113. doi: 10.1016/j.reth.2019.06.002

He, J., Hu, X., Cao, J., Zhang, Y., Xiao, J., Peng, L., et al. (2021). Chitosancoated hydroxyapatite and drug-loaded polytrimethylene carbonate/polylactic acid scaffold for enhancing bone regeneration. Carbohydr. Polym. 253:117198. doi: 10.1016/j.carbpol.2020.117198

He, X., Liu, Y., Tan, Y., Grover, L. M., Song, J., Duan, S., et al. (2019). Rubidiumcontaining mesoporous bioactive glass scaffolds support angiogenesis, osteogenesis and antibacterial activity. Mater. Sci. Eng. C Mater. Biol. Appl. 105:110155. doi: 10.1016/j.msec.2019.110155

Heo, E. Y., Ko, N. R., Bae, M. S., Lee, S. J., Choi, B.-J., Kim, J. H., et al. (2017). Novel $3 \mathrm{D}$ printed alginate-BFP1 hybrid scaffolds for enhanced bone regeneration. J. Ind. Eng. Chem. 45, 61-67. doi: 10.1016/j.jiec.2016.09.003

$\mathrm{Hu}, \mathrm{K}$., and Olsen, B. R. (2016). The roles of vascular endothelial growth factor in bone repair and regeneration. Bone 91, 30-38. doi: 10.1016/j.bone.2016. 06.013

Januariyasa, I. K., Ana, I. D., and Yusuf, Y. (2020). Nanofibrous poly(vinyl alcohol)/chitosan contained carbonated hydroxyapatite nanoparticles scaffold for bone tissue engineering. Mater. Sci. Eng. C Mater. Biol. Appl. 107:110347. doi: 10.1016/j.msec.2019.110347

Kim, H. D., Park, J., Amirthalingam, S., Jayakumar, R., and Hwang, N. S. (2020). Bioinspired inorganic nanoparticles and vascular factor microenvironment directed neo-bone formation. Biomater. Sci. 8, 2627-2637. doi: 10.1039/D0BM00041H

Koc, A., Elcin, A. E., and Elcin, Y. M. (2016). Ectopic osteogenic tissue formation by MC3T3-E1 cell-laden chitosan/hydroxyapatite composite scaffold. Artif. Cell Nanomed. Biotechnol. 44, 1440-1447. doi: 10.3109/21691401.2015.1036998

Lima, D. B., De Souza, M., a..A., De Lima, G. G., Ferreira Souto, E. P., Oliveira, H.M. L., et al. (2020). Injectable bone substitute based on chitosan with polyethylene glycol polymeric solution and biphasic 
calcium phosphate microspheres. Carbohydr. Polym. 245:116575. doi: 10.1016/j.carbpol.2020.116575

Lin, X., Zhao, C., Zhu, P., Chen, J., Yu, H., Cai, Y., et al. (2018). Periosteum extracellular-matrix-mediated acellular mineralization during bone formation. Adv. Healthc. Mater. 7:1700660. doi: 10.1002/adhm.201700660

Loi, F., Cordova, L. A., Pajarinen, J., Lin, T. H., Yao, Z., and Goodman, S. B. (2016). Inflammation, fracture and bone repair. Bone 86, 119-130. doi: 10.1016/j.bone.2016.02.020

Luo, Y., Li, Y., Qin, X., and Wa, Q. (2018). 3D printing of concentrated alginate/gelatin scaffolds with homogeneous nano apatite coating for bone tissue engineering. Mater. Design 146, 12-19. doi: 10.1016/j.matdes.2018.03.002

Lutzweiler, G., Barthes, J., Koenig, G., Kerdjoudj, H., Mayingi, J., Boulmedais, F., et al. (2019). Modulation of cellular colonization of porous polyurethane scaffolds via the control of pore interconnection size and nanoscale surface modifications. ACS Appl. Mater. Interfaces 11, 19819-19829. doi: 10.1021 /acsami.9b04625

Maeno, S., Niki, Y., Matsumoto, H., Morioka, H., Yatabe, T., Funayama, A., et al. (2005). The effect of calcium ion concentration on osteoblast viability, proliferation and differentiation in monolayer and 3D culture. Biomaterials 26, 4847-4855. doi: 10.1016/j.biomaterials.2005.01.006

Melo, P., Naseem, R., Corvaglia, I., Montalbano, G., Pontremoli, C., Azevedo, A., et al. (2020). Processing of $\mathrm{Sr}^{2+}$ containing poly L-lactic acid-based hybrid composites for additive manufacturing of bone scaffolds. Front. Mater. 7:601645. doi: 10.3389/fmats.2020.601645

Mondal, S., Nguyen, T. P., Pham, V. H., Hoang, G., Manivasagan, P., Kim, M. H., et al. (2020). Hydroxyapatite nano bioceramics optimized 3D printed poly lactic acid scaffold for bone tissue engineering application. Ceram. Int. 46, 3443-3455. doi: 10.1016/j.ceramint.2019.10.057

Montalbano, G., Borciani, G., Cerqueni, G., Licini, C., Banche-Niclot, F., Janner, D., et al. (2020). Collagen hybrid formulations for the 3D printing of nanostructured bone scaffolds: an optimized genipin-crosslinking strategy. Nanomaterials 10:1681. doi: 10.3390/nano10091681

Nie, W., Peng, C., Zhou, X., Chen, L., Wang, W., Zhang, Y., et al. (2017). Threedimensional porous scaffold by self-assembly of reduced graphene oxide and nano-hydroxyapatite composites for bone tissue engineering. Carbon N. Y. 116, 325-337. doi: 10.1016/j.carbon.2017.02.013

Oh, S. H., Park, I. K., Kim, J. M., and Lee, J. H. (2007). In vitro and in vivo characteristics of PCL scaffolds with pore size gradient fabricated by a centrifugation method. Biomaterials 28, 1664-1671. doi: 10.1016/j.biomaterials.2006.11.024

Peñarrocha-Diago, M., Bernabeu-Mira, J. C., Fernández-Ruíz, A., Aparicio, C., and Peñarrocha-Oltra, D. (2020). Bone regeneration and soft tissue enhancement around zygomatic implants: retrospective case series. Materials 13:1577. doi: $10.3390 / \mathrm{ma} 13071577$

Peng, L., Cheng, X. R., Wang, J. W., Xu, D. X., and Wang, G. (2016). Preparation and evaluation of porous chitosan/collagen scaffolds for periodontal tissue engineering. J. Bioact. Compat. Poly. 21, 207-220. doi: $10.1177 / 0883911506065100$

Peter, M., Binulal, N. S., Nair, S. V., Selvamurugan, N., Tamura, H., and Jayakumar, R. (2010). Novel biodegradable chitosan-gelatin/nano-bioactive glass ceramic composite scaffolds for alveolar bone tissue engineering. Chem. Eng. J. 158, 353-361. doi: 10.1016/j.cej.2010.02.003

Raynald, Shu, B., Liu, X. B., Zhou, J. F., Huang, H., Wang, J. Y., Sun, X. D., et al. (2019). Polypyrrole/polylactic acid nanofibrous scaffold cotransplanted with bone marrow stromal cells promotes the functional recovery of spinal cord injury in rats. CNS Neurosci. Ther. 25, 951-964. doi: 10.1111/cns. 13135

Ribeiro, T. O., Silveira, B. M., Meira, M. C., Carreira, A.C. O., Sogayar, M. C., Meyer, R., et al. (2019). Investigating the potential of the secretome of mesenchymal stem cells derived from sickle cell disease patients. PLOS ONE 14:e0222093. doi: 10.1371/journal.pone.0222093

Roosa, S. M., Kemppainen, J. M., Moffitt, E. N., Krebsbach, P. H., and Hollister, S. J. (2010). The pore size of polycaprolactone scaffolds has limited influence on bone regeneration in an in vivo model. J. Biomed. Mater. Res. A 92, 359-368. doi: $10.1002 / \mathrm{jbm}$.a.32381

Saleem, M., Rasheed, S., and Yougen, C. (2020). Silk fibroin/hydroxyapatite scaffold: a highly compatible material for bone regeneration. Sci. Technol. Adv. Mater. 21, 242-266. doi: 10.1080/14686996.2020.1748520
Sharmila, G., Muthukumaran, C., Kirthika, S., Keerthana, S., Kumar, N. M., and Jeyanthi, J. (2020). Fabrication and characterization of Spinacia oleracea extract incorporated alginate/carboxymethyl cellulose microporous scaffold for bone tissue engineering. Int. J. Biol. Macromol. 156, 430-437. doi: 10.1016/j.ijbiomac.2020.04.059

Shen, J., Chen, B., Zhai, X., Qiao, W., Wu, S., Liu, X., et al. (2021). Stepwise 3Dspatio-temporal magnesium cationic niche: nanocomposite scaffold mediated microenvironment for modulating intramembranous ossification. Bioact. Mater. 6, 503-519. doi: 10.1016/j.bioactmat.2020.08.025

Shi, X., Sitharaman, B., Pham, Q. P., Liang, F., Wu, K., Edward Billups, W., et al. (2007). Fabrication of porous ultra-short single-walled carbon nanotube nanocomposite scaffolds for bone tissue engineering. Biomaterials 28 , 4078-4090. doi: 10.1016/j.biomaterials.2007.05.033

Shie, M. Y., and Ding, S. J. (2013). Integrin binding and MAPK signal pathways in primary cell responses to surface chemistry of calcium silicate cements. Biomaterials 34, 6589-6606. doi: 10.1016/j.biomaterials.2013.05.075

Smith, C. A., Richardson, S. M., Eagle, M. J., Rooney, P., Board, T., and Hoyland, J. A. (2015). The use of a novel bone allograft wash process to generate a biocompatible, mechanically stable and osteoinductive biological scaffold for use in bone tissue engineering. J. Tissue Eng. Regen. Med. 9, 595-604. doi: 10.1002/term.1934

Sukhodub, L. B., Yanovska, G. O., Kuznetsov V. M., Martynyuk, O. O., and Sukhodub, L.F. (2016). Injectable biopolymer-hydroxyapatite hydrogels: obtaining and their characterization. J. Nano Electr. Phys. 8:01032. doi: 10.21272/jnep.8(1).01032

Tohamy, K. M., Mabrouk, M., Soliman, I. E., Beherei, H. H., and Aboelnasr, M. A. (2018). Novel alginate/hydroxyethyl cellulose/hydroxyapatite composite scaffold for bone regeneration: in vitro cell viability and proliferation of human mesenchymal stem cells. Int. J. Biol. Macromol. 112, 448-460. doi: 10.1016/j.ijbiomac.2018.01.181

Uccelli, A., Wolff, T., Valente, P., Di Maggio, N., Pellegrino, M., Gurke, L., et al. (2019). Vascular endothelial growth factor biology for regenerative angiogenesis. Swiss Med. Wkly. 149:w20011. doi: 10.4414/smw.2019.20011

Wei, J., Wang, Y., Jiang, J., Yan, Y., Fan, D., Yang, X., et al. (2019). Development of an antibacterial bone graft by immobilization of levofloxacin hydrochlorideloaded mesoporous silica microspheres on a porous scaffold surface. J. Biomed. Nanotechnol. 15, 1097-1105. doi: 10.1166/jbn.2019.2743

Wei, S., Ma, J. X., Xu, L., Gu, X. S., and Ma, X. L. (2020). Biodegradable materials for bone defect repair. Mil. Med. Res. 7:54. doi: 10.1186/s40779-020-00280-6

Wijesinghe, W. P. S. L., Mantilaka, M. M. M. G. P. G., Rajapakse, R. M. G., Pitawala, H. M. T. G. A., Premachandra, T. N., Herath, H. M. T. U., et al. (2017). Urea-assisted synthesis of hydroxyapatite nanorods from naturally occurring impure apatite rocks for biomedical applications. RSC Adv. 7, 24806-24812. doi: 10.1039/C7RA02166F

Windhager, R., Hobusch, G. M., and Matzner, M. (2017). Allogeneic transplants for biological reconstruction of bone defects. Orthopade 46, 656-664. doi: 10.1007/s00132-017-3452-0

Witek, L., Shi, Y., and Smay, J. (2017). Controlling calcium and phosphate ion release of 3D printed bioactive ceramic scaffolds: an in vitro study. J. $A d v$. Ceram. 6, 157-164. doi: 10.1007/s40145-017-0228-2

Yang, J., Wang, Q, Wang, Y., Han, S., Yao, J., Shao, S., et al. (2015). Preparation and in vitro release of multilayer alginate chitosan microspheres loading VEGF and vancomycin. Chem. J. Chin. Univ. 36, 1025-1032. doi: 10.7503/cjcu20140992

You, Y., Keqiqu, Huang, Z., Ma, R., Shi, C., Li, X., Liu, D., et al. (2019). Sodium alginate templated hydroxyapatite/calcium silicate composite adsorbents for efficient dye removal from polluted water. Int. J. Biol. Macromol. 141, 1035-1043. doi: 10.1016/j.ijbiomac.2019.09.082

Yu, L., Fei, Q., Lin, J., Yang, Y., and Xu, Y. (2020). The osteogenic effect of local delivery of vancomycin and tobramycin on bone marrow stromal cells. Infect. Drug Resist. 13, 2083-2091. doi: 10.2147/IDR.S261767

Zhang, C., Shao, K, Liu, C., Li, C., and Yu, B. (2019). Hypoxic Preconditioning BMSCs-exosomes inhibit cardiomyocyte apoptosis after acute myocardial infarction by upregulating microRNA-24. Eur. Rev. Med. Pharmacol. Sci. 23, 6691-6699. doi: 10.26355/eurrev_201908 18560

Zhou, X., Weng, W., Chen, B., Feng, W., Wang, W., Nie, W., et al. (2018). Mesoporous silica nanoparticles/gelatin porous composite scaffolds with localized and sustained release of vancomycin for treatment of 
infected bone defects. J. Mater. Chem. B 6, 740-752. doi: 10.1039/C7TB0 1246B

Zima, A., Czechowska, J., Szponder, T., and Slosarczyk, A. (2020). In vivo behavior of biomicroconcretes based on alpha-tricalcium phosphate and hybrid hydroxyapatite/chitosan granules and sodium alginate. J. Biomed. Mater. Res. A 108, 1243-1255. doi: 10.1002/jbm.a. 36898

Zou, Z., Wang, L., Zhou, Z., Sun, Q., Liu, D., Chen, Y., et al. (2021). Simultaneous incorporation of $\mathrm{PTH}(1-34)$ and nano-hydroxyapatite into Chitosan/Alginate Hydrogels for efficient bone regeneration. Bioact. Mater. 6, 1839-1851. doi: 10.1016/j.bioactmat.2020.11.021
Conflict of Interest: The authors declare that the research was conducted in the absence of any commercial or financial relationships that could be construed as a potential conflict of interest.

Copyright (c) $2021 \mathrm{Liu}, \mathrm{Liu}, \mathrm{Zou}, \mathrm{Li}$, Sui, Wang, Yang and Wang. This is an openaccess article distributed under the terms of the Creative Commons Attribution License (CC BY). The use, distribution or reproduction in other forums is permitted, provided the original author(s) and the copyright owner(s) are credited and that the original publication in this journal is cited, in accordance with accepted academic practice. No use, distribution or reproduction is permitted which does not comply with these terms. 